72 Inorg. Chem. 2011, 50, 72-85

DOI: $10.1021 /$ ic101212y

\title{
Zn(II) Complexes of Glutathione Disulfide: Structural Basis of Elevated Stabilities
}

\author{
Artur Krężel, ${ }^{, \dagger}$ Jacek Wójcik, ${ }^{\ddagger}$ Maciej Maciejczyk, ${ }^{\S}$ and Wojciech Bal ${ }^{, \neq, \|}$ \\ ${ }^{\dagger}$ Laboratory of Protein Engineering, Faculty of Biotechnology, University of Wrockaw, Tamka 2, \\ 50-137 Wrockaw, Poland, "Institute of Biochemistry and Biophysics, Polish Academy of Sciences, \\ Pawińskiego 5a, 02-106 Warsaw, Poland, ${ }^{\S}$ Department of Physics and Biophysics, \\ University of Warmia and Mazury, Oczapowskiego 4, 10-719, Olsztyn, Poland, and \\ "Central Institute for Labour Protection-National Research Institute, \\ Czerniakowska 16,00-701 Warsaw, Poland
}

Received June 17, 2010

\begin{abstract}
Glutathione disulfide (GSSG), a long disregarded redox partner of glutathione (GSH), is thought to participate in intracellular zinc homeostasis. We performed a concerted potentiometric and NMR spectroscopic study of protonation and $\mathrm{Zn}(\mathrm{II})$ binding properties of GSSG $\left((\gamma \mathrm{ECG})_{2}\right)$ and a series of its nine analogs with C-terminal modifications, tripeptide disulfides: $(\gamma \mathrm{ECS})_{2},(\gamma \mathrm{ECE})_{2},\left(\gamma \mathrm{ECG}-\mathrm{NH}_{2}\right)_{2},(\gamma \mathrm{ECG}-\mathrm{OEt})_{2}$, and $(\gamma \mathrm{EcG})_{2}$; dipeptide disulfides, $(\gamma \mathrm{EC})_{2}$ and $(\gamma \text { EC-OEt })_{2}$; and mixed disulfides, $\gamma$ ECG- $\gamma$ EC and $\gamma$ ECG- $\gamma$ EC-OEt. The acid-base and Zn(II) complexation properties in this group of compounds are strictly correlated to average $\mathrm{C}$-terminal electrostatic charges. In particular, it was demonstrated that GSSG assumes a bent (head-to-tail) conformation in solution at neutral pH, which is controlled by electrostatic attraction between the protonated $\gamma$-amino groups of the Glu residue and the deprotonated C-terminal Gly carboxylates. This interaction modulates the ability of GSSG to coordinate Zn(II), both indirectly, by affecting the basicities of the amino groups, and directly, through the participation of the Gly carboxylates in the outer coordination sphere of the $\mathrm{Zn}(\mathrm{II})$ ion. A specific coiled structure of the major $[\mathrm{Zn}-\mathrm{GSSG}]^{2-}$ complex is additionally stabilized by the formation of hydrogen bonds between glycinyl carboxylates and two $\mathrm{Zn}(\mathrm{II})$-coordinated water molecules. The elevated stability of Zn(II)-GSSG complexes was demonstrated by competition with FluoZin-3, a fluorescent sensor with high $\mathrm{Zn}(\mathrm{II})$ affinity, commonly used in in vitro and in vivo studies. The potential biological functions and reactivity of GSSG complexes of $\mathrm{Zn}(\mathrm{II})$ ions are discussed.
\end{abstract}

\section{Introduction}

Glutathione disulfide (GSSG), also known as oxidized glutathione, is the primary product of oxidation of GSH, the predominant nonprotein cellular thiol, which is crucial for antioxidant defense, xenobiotic metabolism, maintenance of cellular membranes, and many other functions. ${ }^{1,2}$ The cytosolic concentration of GSSG, much lower than GSH, is controlled by a specific export system. ${ }^{1,2}$ The earlier research has therefore concentrated on GSH, with GSSG disregarded as a mere byproduct of GSH reactivity. Novel findings stress the importance of the actual GSH/GSSG balance. It is estimated to account for over $90 \%$ of the control of the intracellular redox potential, ${ }^{3}$ and as presented recently, it controls the pacing of protein turnover, via the control of

*To whom correspondence should be addressed. Phone: +48-71-375-2765 (A.K.), +48-22-592-2346 (W.B.). Fax: +48-71-375-2608 (A.K.), +48-22658-4636 (W.B.). E-mail: art@protein.pl (A.K.), wbal@ibb.waw.pl (W.B.).

(1) Sies, H. Free Radic. Biol. Med. 1999, 27, 916-921.

(2) Dickinson, D. A.; Forman, H. J. Biochem. Pharmacol. 2002, 64, 10191026 .

(3) Schafer, F. Q.; Buettner, G. R. Free Radic. Biol. Med. 2001, 30, 11911212 . cathepsin B activity. ${ }^{4}$ The latter function may be one example of an emerging concept of redox signaling, as a major system of coordination of cell functions. ${ }^{5}$ The formation of mixed disulfides in a reaction of GSSG with protein thiols is one of several postulated pathways in this system. ${ }^{6}$ Another specific function, discovered for GSSG, is the regulation of $\mathrm{Zn}$ (II) content of metallothionein, which couples the redox state of the cell with zinc metabolism. ${ }^{7-9}$ Typical total zinc concentrations of a eukaryotic cell range between approximately 200 and $300 \mu \mathrm{M}$ and do not vary significantly from one physiological state to another. ${ }^{9,10}$ However, concentrations of thermodynamically and kinetically available zinc ("free" zinc) vary

(4) Lockwood, T. D. Arch. Biochem. Biophys. 2003, 417, 183-193.

(5) Kim, S. O.; Merchant, K.; Nudelman, R.; Beyer, W. F., Jr.; Keng, T.; DeAngelo, J.; Hausladen, A.; Stamler, J. S. Cell 2002, 109, 383-396.

(6) Casagrande, S.; Bonetto, V.; Fratelli, M.; Gianazza, E.; Eberini, I.; Massignan, T.; Salmona, M.; Chang, G.; Holmgren, A.; Ghezzi, P. Proc. Natl. Acad. Sci. U.S.A. 2002, 99, 9745-9749.

(7) Jiang, L. J.; Maret, W.; Vallee, B. L. Proc. Natl. Acad. Sci. U.S.A. 1998, 95, 3483-3488.

(8) Kreżel, A.; Maret, W. Biochem. J. 2006, 402, 551-558.

(9) Krȩżel, A.; Maret, W. J. Biol. Inorg. Chem. 2006, 11, 1049-1062.

(10) Li, Y.; Maret, W. Exp. Cell Res. 2009, 315, 2463-2470. 
by several orders of magnitude and are strongly dependent on cellular compartmentalization. ${ }^{11-13}$ Recent studies clearly demonstrate "free" zinc concentration at a level of hundreds of pM in various types of eukaryotic cells, indicating a strong binding and tight buffering of this metal ion. ${ }^{9,14-17}$ In particular, studies made with HT-29 human colorectal adenocarcinoma cells shed more light on correlations between cellular redox states dependent on GSH/GSSG ratios (potential variation between -260 and $-160 \mathrm{mV}$ ) and "free" zinc, metallothionein (MT), and thionein (apometallothionein, $\mathrm{T}_{\mathrm{R}}$ ) levels. ${ }^{8,9,18}$ The elevation of GSSG concentration in HT-29 cells induced by cell differentiation or apoptosis caused an increase of "free" zinc concentration and a significant decrease of the T/MT ratio (due to the formation of MT and oxidized thionin, $\left.\mathrm{T}_{\mathrm{Ox}}\right){ }^{8,9,19}$ Studies in human cell lines indicate that both GSH and GSSG have their separate roles in zinc toxicity. ${ }^{20}$ It has also been hypothesized that zinc and $\mathrm{GSH}$, together with nitric oxide, collectively protect against a host of diseases. ${ }^{21}$

The overall GSSG concentration within the cell under normal conditions is ca. $0.5 \%$ that of GSH. Taking into account that the GSH level may reach $10 \mathrm{mM}$, the "normal" GSSG concentration in the cell cytosol might be as high as $50 \mu \mathrm{M}$. Moreover, compartmentalization of GSH/GSSG may lead to elevated GSSG concentrations locally. ${ }^{22,23}$ GSH/GSSG ratios as low as 1:1 are thought to occur in the endoplasmic reticulum. ${ }^{24}$ Also, under various stress conditions, the overall GSSG level may be elevated. ${ }^{3,4}$

The low level of GSSG inside the cell is maintained by active export of this molecule across the cellular membrane. Therefore, high GSSG concentrations should be expected locally near the outer cell surface. ${ }^{1,2}$ However, no quantitative data are available in this respect.

A molecule of GSSG contains two amine functions and four carboxylates. This donor set is qualitatively similar to that of ethylendiaminetetraacetic acid (EDTA), although with a much bigger separation of respective coordination sites (Scheme 1). Therefore, GSSG can be expected to be a versatile ligand for many metal ions. Despite that, not so many studies of GSSG coordination abilities were published, all with the

(11) Tomat, T. E.; Nolan, E. M.; Jaworski, J.; Lippard, S. J. J. Am. Chem. Soc. 2008, 130, 15776-15777.

(12) Colvin, R. A.; Laskowski, M.; Fontaine, C. P. Brain Res. 2006, 1085, $1-10$.

(13) Maret, W.; Li, Y. Chem. Rev. 2009, 109, 4682-4707.

(14) Vinkenborg, J. L.; Nicolson, T. J.; Bollomo, E. A.; Koay, M. S.; Rutter, G. A.; Merkx, M. Nat. Methods 2009, 6, 737-740.

(15) Atar, D.; Backx, P. H.; Appel, M. M.; Gao, W. D.; Marben, E. J. Biol. Chem. 1995, 270, 2473-2477.

(16) Ayaz, M.; Turan, B. Am. J. Physiol. Heart Circ. Physiol. 2006, 290, H1071-H1080.

(17) Haase, H.; Hebel, S.; Engelhardt, G.; Rink, L. Anal. Biochem. 2006, $352,222-230$

(18) Kirlin, W. G.; Cai, K.; Thompson, S. A.; Diaz, D.; Kavanagh, T. J.; Jones, D. P. Free Radic. Biol. Med. 1999, 27, 1208-1218.

(19) Krężel, A.; Hao, Q.; Maret, W. Arch. Biochem. Biophys. 2007, 463, $188-200$.

(20) Walther, U. I.; Czermak, A.; Muckter, H.; Walther, S. C.; Fichtl, B. Arch. Toxicol. 2003, 77, 131-137.

(21) Sprietsma, J. E. Med. Hypotheses 1999, 53, 6-16.

(22) Soderdahl, T.; Enoksson, M.; Lundberg, M.; Holmgren, A.; Ottersen, O. P.; Orrenius, S.; Bolcsfoldi, G.; Cotgreave, I. A. FASEB J. 2003, 17, 124 126.

(23) Monostori, P.; Wittmann, G.; Karg, E.; Turi, S. J. Chromatogr., B 2009, 877, 3331-3346.

(24) Hwang, C.; Sinskey, A. J.; Lodish, H. F. Science 1992, 257, 14961502 .

(25) Krężel, A.; Bal, W. Acta Biochim. Pol. 1999, 46, 567-580.
Scheme 1. Structures of Tri- and Dipeptide $\gamma$-Glutamyl Disulfides Studied in This Work, Presented in Their Fully Protonated Forms

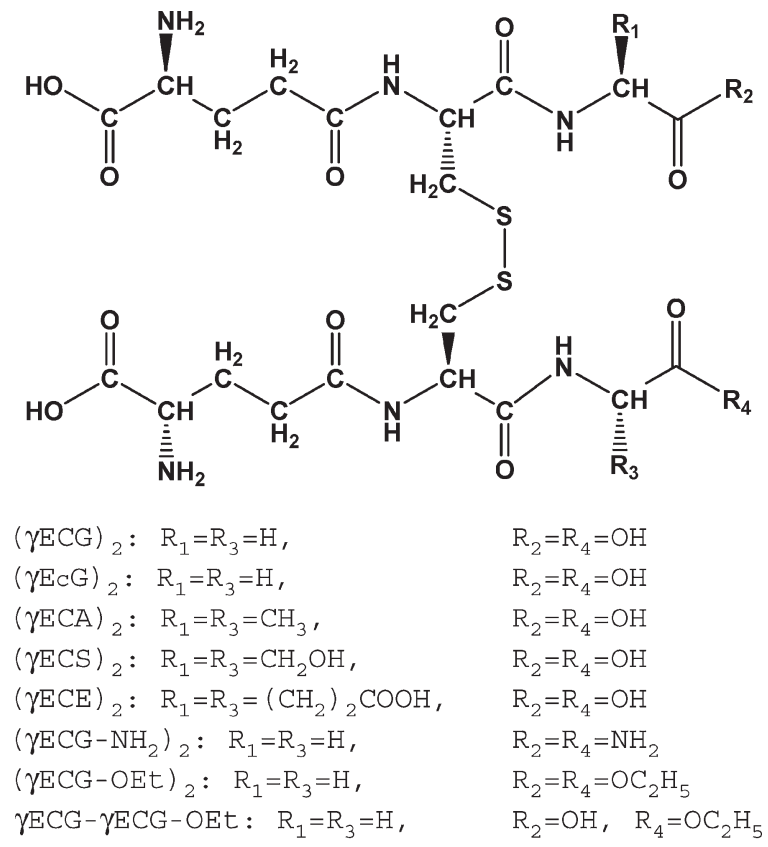<smiles>[R6]C(=O)[C@H](CSSC[C@H](NC(=O)CC[C@H](N)C(=O)O)C([R6])=O)NC(=O)CC[C@H](N)C(=O)O</smiles>

$(\gamma \mathrm{EC})_{2}: \mathrm{R}_{5}=\mathrm{R}_{6}=\mathrm{OH}$, $\gamma \mathrm{ECG}-\gamma \mathrm{EC}: \mathrm{R}_{5}=\mathrm{OH}$,<smiles>[R5]NCC(=O)O</smiles>

metal ions of the first transition row. ${ }^{25,26}$ The amine/carboxylate donor set of the Glu moiety is the primary metal binding site. This set, analogous to those present in simple $\alpha$-amino acids, is a unique feature of GSH and GSSG, due to the presence of a $\gamma$-peptidic bond. The two such sites in GSSG may bind metal ions in a concerted way, with an ML-type stoichiometry $\left(\mathrm{MH}_{n} \mathrm{~L}\right.$, with $n$ between 3 and -1$)$, or independently, resulting in $\mathrm{M}_{2} \mathrm{~L}$-type complexes $\left(\mathrm{M}_{2} \mathrm{H}_{n} \mathrm{~L}\right.$, with $n$ between 0 and -4). The equilibrium between ML-type and $\mathrm{M}_{2} \mathrm{~L}$-type complexes depends primarily on metal-to-ligand ratios. The metal ions in an $\mathrm{M}_{2} \mathrm{~L}$ complex may, in principle, be the same, or different, but no heterometallic cases have been reported to date.

Only three preceding papers on Zn(II) coordination to GSSG were published. Potentiometry was applied as the sole experimental technique in two of them. ${ }^{27,28} \mathrm{ZnHL}, \mathrm{ZnL}$, and $\mathrm{Zn}_{2} \mathrm{~L}$ complexes were postulated to exist in solution. ${ }^{27}$

(26) Krężel, A.; Bal., W. Bioinorg. Chem. Appl. 2004, 293-305. 
The remaining study used ${ }^{1} \mathrm{H}$ and ${ }^{13} \mathrm{C}$ NMR.${ }^{29}$ However, the relatively high stability of the $\mathrm{ZnL}$ complex, apparent from those studies, has neither been noted nor discussed in thermodynamic or structural terms. These issues have now gained importance in the light of biochemical discoveries regarding the potential physiological roles for Zn(II) - GSSG interactions, mentioned above. The participation of the Gly carboxylate in $\mathrm{Zn}(\mathrm{II})$ coordination was discussed on the basis of $1 \mathrm{D}$ NMR spectra, with a conclusion that no interaction occurred. ${ }^{29}$

Our study on conformational preferences of GSH and its analogs indicated a strong influence of the $\mathrm{C}$-terminal residue on acid-base properties of the N-terminal moiety in these molecules. ${ }^{30}$ This property, overlooked in preceding works, was demonstrated clearly in a series of C-terminally substituted peptides. Therefore, we decided to repeat this successful strategy and undertook a systematic study of $\mathrm{Zn}$ (II) complexation to GSSG and its analogs, using NMR and potentiometry in a concerted fashion, to correlate thermodynamic and structural properties of these complexes and thereby obtain better insight into their possible interactions in vivo.

\section{Experimental Section}

Materials. Peptides glutathione disulfide (GSSG), monoethyl ester of glutathione (GSH-OEt), glutathione sulfonic acid $\left(\mathrm{GSO}_{3} \mathrm{H}\right)$ and S-methylglutathione (GSMe), L-glutamic acid, ethylendiaminetetracetic acid disodium salt dihydrate (EDTA), (4-(2-hydroxyethyl)piperazine-1-ethanesulfonic acid (HEPES), $\mathrm{NaOD}\left(40 \% \mathrm{w} / \mathrm{v}\right.$ in $\left.\mathrm{D}_{2} \mathrm{O}\right)$, 4-nitrophenyl acetate, and tris (4-nitrophenyl) phosphate were obtained from Sigma-Aldrich. The peptides $\gamma$-EC and $\gamma$-EC-OEt were purchased from Bachem. Zinc sulfate heptahydrate $\left(\mathrm{ZnSO}_{4} \cdot 7 \mathrm{H}_{2} \mathrm{O}\right)$, potassium nitrate $\left(\mathrm{KNO}_{3}\right), 0.1 \mathrm{M} \mathrm{NaOH}$ solution in water (titrant), methanol, and ethanol were obtained from Merck KGaA. FluoZin-3 tetrapotassium salt was from Invitrogen. $\mathrm{D}_{2} \mathrm{O}$ and $\mathrm{DCl}(30 \%$ $\mathrm{w} / \mathrm{v}$ in $\mathrm{D}_{2} \mathrm{O}$ ) were purchased from Cambridge Isotope Laboratories, Inc. 3-(Trimethylsilyl)-1-propanesulfonic acid (DSS) was from Dr. Glaser AG. Acetic anhydrate $\left(\mathrm{Ac}_{2} \mathrm{O}\right)$, sodium hydroxide (solid), 35\% aqueous hydrochloric acid, diethyl ether $\left(\mathrm{Et}_{2} \mathrm{O}\right)$, and hydrogen peroxide $\left(\mathrm{H}_{2} \mathrm{O}_{2}, 30 \%\right.$, analytical grade) were obtained from POCH (Gliwice, Poland).

Peptide Synthesis. The reduced thiol peptides $\gamma$-Glu-Cys-Ser $(\gamma$ ECS $), \gamma$-Glu-Cys-Glu $\left(\gamma\right.$ ECE), and $\gamma$-Glu-Cys-Gly- $\mathrm{NH}_{2}$ $\left(\gamma\right.$ ECG-NH$\left.{ }_{2}\right)$ were synthesized in the solid state according to the Fmoc strategy, as described before. ${ }^{30}$ The $\gamma$-Glu-D-Cys-Glu peptide $(\gamma \mathrm{EcG})$ was also synthesized using the Fmoc strategy, but on a 2-chlorotrityl chloride resin. ${ }^{31,32}$ The N-Fmoc-protected amino acids N-Fmoc-Gly-OH and N-Fmoc-D-Cys-(Mtt)-OH were obtained from Nova Biochem (Merck KGaA), while the $\mathrm{N}$-terminal $\mathrm{N}-t \mathrm{Boc}-\mathrm{Glu}-(\alpha-t \mathrm{Bu})$ was obtained from Sigma-Aldrich. The coupling agents 1-hydroxybenzotriazole (HOBt) and dicyclohexylcarbodiimide (DCC) were purchased from Merck $\mathrm{KGaA}$; solvents trifluoroacetic acid, 2,2,2-trifluorotehanol, piperidine, acetonitrile, $N, N$-dimethylformide (DMF), and dichloromethane (DCM) were obtained from Riedel-de Haën $\mathrm{GmbH}$ (Seeize, Germany). Fmoc protection groups were removed by

(27) Varnagy, K.; Sovago, I.; Kozłowski, H. Inorg. Chim. Acta 1988, 151, $117-123$.

(28) Li, N. C.; Gawron, O.; Bascuas, G. J. Am. Chem. Soc. 1954, 76, $225-$ 229.

(29) Postal, W. S.; Vogel, E. J.; Young, C. M.; Greenaway, F. T. J. Inorg. Biochem. 1985, 25, 25-33.

(30) Krężel, A.; Bal, W. Org. Biomol. Chem. 2003, 1, 3885-3890.

(31) White, P. D.; Chan, W. C. In Fmoc Solid Phase Peptide Synthesis. A Practical Approach; Chan, W. C.; White, P. D., Eds.; Oxford University Press: New York, 2000; pp 9-39.

(32) Guy, C. A.; Fields, G. B. Methods Enzymol. 1997, 289, 67-83.
$25 \%$ piperidine in DMF. The coupling was monitored using the Keiser (ninhydrin) test and TLC. The scale of synthesis was ca. $1.3 \mathrm{mmol}$ in terms of resin substitution; a 2.5 -fold excess of amino acids was used for additions. The cleavage was effected using a mixture of trifluoroacetic acid, trifluoroethanol, dichloromethane, and dimercaptoglycol (v/v/v/v = 3:1:5:1) over a period of $24 \mathrm{~h}$, followed by precipitation with cold diethyl ether; peptide cleavage from the resin; removal of the protecting groups $\mathrm{Mtt}$, Boc, and $t \mathrm{Bu}$; and washing with diethyl ether. The yield of the crude unprotected peptides, complexed with TFA, was $30-50 \%$. The final purification was done using HPLC (Hewlett-Packard) on an Alltech Econsil C18 10U preparative column $(22 \times 250 \mathrm{~mm}, 5 \mu \mathrm{m}$ grain $)$, in a $0-100 \% 0.1 \%$ $\mathrm{TFA} /$ water to $0.1 \% \mathrm{TFA} /$ acetonitrile gradient, detected at $200 \mathrm{~nm}$. The disulfides of all thiol peptides listed above were synthesized either by oxidation with elemental iodine in water solution or by oxidation with atmospheric oxygen in alkaline water solution (controlled with $\mathrm{NaOH}$ ) followed by purification on HPLC, as described above. The $\mathrm{pH}$ value of 9.2 was chosen as optimal for air oxidation of glutathione and its analogs, on the basis of our previous experiments. ${ }^{33}$ The mixed disulfides $\gamma$ ECG- $\gamma$ EC and $\gamma$ ECG- $\gamma$ EC-OEt were obtained by oxygenation of equimolar solutions of respective thiol peptides at constant $\mathrm{pH}, 9.6$ and 9.8, respectively. The reactions were monitored and purified by HPLC as described above. The purities and identities of all synthesized peptides for the purpose of this study were finally confirmed by mass spectrometry, on a Finnigan MAT TSQ 700 instrument. The $m / z$ values found/ calculated were for $(\gamma \mathrm{ECS})_{2}: 673.1 / 673.2(\mathrm{M}+\mathrm{H})^{+}$and 337.5/ $338.1(\mathrm{M}+2 \mathrm{H})^{2+}$; for $(\gamma \mathrm{ECE})_{2}: 756.8 / 757.2(\mathrm{M}+\mathrm{H})^{+}$and $379.7 /$ $380.1(\mathrm{M}+2 \mathrm{H})^{2+}$; for $\left(\gamma \mathrm{ECG}-\mathrm{NH}_{2}\right)_{2}: 610.6 / 611.2(\mathrm{M}+\mathrm{H})^{+}$and $307.3 / 307.1(\mathrm{M}+2 \mathrm{H})^{2+}$; for $(\gamma \mathrm{ECG}-\mathrm{OEt})_{2}: 668.6 / 669.2(\mathrm{M}+\mathrm{H})^{+}$ and $336.3 / 336.1(\mathrm{M}+2 \mathrm{H})^{2+}$; for $(\gamma \mathrm{EC})_{2}: 499.3 / 499.1(\mathrm{M}+\mathrm{H})^{+}$ and $250.6 / 251.1(\mathrm{M}+2 \mathrm{H})^{2+}$; for $\gamma \mathrm{ECG}-\gamma \mathrm{EC}: 555.8 / 556.1$ $(\mathrm{M}+\mathrm{H})^{+}$and $279.2 / 279.6(\mathrm{M}+2 \mathrm{H})^{2+}$; for $\gamma \mathrm{ECG}-\gamma \mathrm{EC}-\mathrm{OEt}:$ $640.9 / 641.2(\mathrm{M}+\mathrm{H})^{+}$and $321.7 / 322.1(\mathrm{M}+2 \mathrm{H})^{2+}$; for $(\gamma \mathrm{EcG})_{2}$ : $613.5 / 613.2(\mathrm{M}+\mathrm{H})^{+}$and 307.7/308.1 $(\mathrm{M}+2 \mathrm{H})^{2+}$.

Thermodynamic Studies. The protonation and $\mathrm{Zn}(\mathrm{II})$ stability constants of GSSG in the presence of $\mathrm{KNO}_{3}(I=0.1 \mathrm{M})$ were determined at $19,25,30$, and $37^{\circ} \mathrm{C}$ using $\mathrm{pH}$-metric titrations over the $\mathrm{pH}$ range $2.5-11.0$ (Molspin automatic titrator, Molspin Ltd.) with $0.1 \mathrm{M} \mathrm{NaOH}$ as a titrant. Changes of $\mathrm{pH}$ were monitored with a combined glass $-\mathrm{Ag} / \mathrm{AgCl}$ electrode (InLab 422, Mettler Toledo) calibrated daily in hydrogen concentrations using $4 \mathrm{mM} \mathrm{HNO}_{3}$ titrations $(I=0.1 \mathrm{M}) .{ }^{34}$ Sample volumes of $1.5-2.0 \mathrm{~mL}$ and concentrations of $1-2 \mathrm{mM}$ ligands and $0-2 \mathrm{mM} \mathrm{Zn}(\mathrm{II})$ were used. The experimental data were analyzed using the SUPERQUAD software. ${ }^{35}$ Standard deviations computed by SUPERQUAD refer to random errors. The $\Delta H$ and $T \Delta S$ values were obtained from linear fits of temperature dependences of $\Delta G$ values, calculated from values of $\ln$ $K_{\mathrm{i}}(\mathrm{T})$ of individual protonation and complex formation reactions. Standard deviations of these quantities derive from these linear fits. The protonation and $\mathrm{Zn}$ (II) stability constants for other compounds reported in this paper were obtained, at $25^{\circ} \mathrm{C}$ only, by the same methodology.

NMR Spectrometry. ${ }^{1} \mathrm{H}$ NMR spectra of GSSG were recorded on a Bruker AMX-300 spectrometer at $300 \mathrm{MHz}$ or a UNITY500plus spectrometer (Varian Inc.), equipped with a waveform generator unit Performa II, a high stability temperature unit, and a $5 \mathrm{~mm}{ }^{1} \mathrm{H}\left\{{ }^{13} \mathrm{C} /{ }^{15} \mathrm{~N}\right\}$ PFG triple probe, at 500.606 $\mathrm{MHz} . \mathrm{D}_{2} \mathrm{O}$ was used as a solvent for all samples. The spectra are expressed in $\delta(\mathrm{ppm})$ relative to DSS, which was used as an

(33) Krẹżel, A.; Szczepanik, W.; Sokołowska, M.; Jeżowska-Bojczuk, M.; Bal, W. Chem. Res. Toxicol. 2003, 16, 855-864.

(34) Irving, H.; Miles, M. G.; Pettit, L. D. Anal. Chim. Acta 1967, 38, 475488.

(35) Gans, P.; Sabatini, A.; Vacca, A. J. Chem. Soc., Dalton Trans. 1985, $1195-1200$. 
internal standard in one-dimensional spectra at $300 \mathrm{MHz}$. The $1 \mathrm{D}$ and 2D spectra at $500 \mathrm{MHz}$ were calibrated using the HDO signal at $4.78 \mathrm{ppm}^{36} 10 \mathrm{mM} \mathrm{GSSG}$ and 0 or $10 \mathrm{mM} \mathrm{Zn(II)} \mathrm{were}$ used for ${ }^{1} \mathrm{H}$ experiments at $300 \mathrm{MHz}$. In a separate set of ${ }^{1} \mathrm{H}$ experiments at $500 \mathrm{MHz}$, the 1:1 samples of GSSG and $\mathrm{Zn}$ (II) were measured in a concentration range of $0.1-100 \mathrm{mM}$. Simulations of 1D NMR proton spectra which yielded chemical shifts and coupling constants of Gly protons were performed with the program NMRSIM, kindly provided by professor W. Danikiewicz, Institute of Organic Chemistry, Polish Academy of Sciences, Warsaw, Poland. The $1 \mathrm{D}^{13} \mathrm{C}$ spectra of GSSG and its $\mathrm{Zn}\left(\mathrm{II}\right.$ ) complex in $\mathrm{D}_{2} \mathrm{O}$, $\mathrm{pH}^{*}$ (uncorrected readings in $\mathrm{D}_{2} \mathrm{O}$ of a pH-meter calibrated with standard buffers in $\mathrm{H}_{2} \mathrm{O}$ ) 8.2, at a 1:1 ratio, were measured on a UNITY500plus spectrometer at $125.889 \mathrm{MHz}$, in a concentration range of $25 \mathrm{mM}$ to $100 \mathrm{mM}$. The 2D NMR spectra of GSSG, GSSG-(OEt) 2 , and their Zn(II) complexes were recorded for disulfide and $\mathrm{Zn}(\mathrm{II})$ concentrations of $20 \mathrm{mM}$ in $\mathrm{D}_{2} \mathrm{O}$, at $\mathrm{pH}^{*} 8.4$ for $\mathrm{GSSG}$ and 8.8 for GSSG-(OEt) $)_{2}$. The ROESY experiments ${ }^{37,38}$ were measured in 256 increments and with 0.25 or $0.4 \mathrm{~s}$ mixing times. The $\left\{{ }^{1} \mathrm{H} /{ }^{13} \mathrm{C}\right\}$ gHSQC experiments ${ }^{39,40}$ were performed in the proton decoupled mode, with a carbon spectral width of $30 \mathrm{k}$ and 512 increments. The spectra were recorded at $25^{\circ} \mathrm{C}$.

Structure Calculations. Volumes of cross-peaks provided by ROESY spectra were calibrated for interproton distances according to the common formula $V=A / R^{6}$. The calculation of parameter $A$ was based on the fact that the highest cross-peak measured corresponded to a distance of $2.4 \AA$ (see Supporting Information Tables S1 and S2). In this way, the lowest crosspeaks corresponded to distances of $5 \AA$ and $5.8 \AA$ for $\mathrm{Zn}$ (II) - GSSG and $\mathrm{Zn}(\mathrm{II})-(\gamma \mathrm{ECG}-\mathrm{OEt})_{2}$, respectively. Thirteen structurally relevant restraints, including seven inter-residual ones, were included in the simulated annealing procedure for the $\mathrm{Zn}(\mathrm{II})-\mathrm{GSSG}$ complex. The numbers of restraints for the $\mathrm{Zn}$ (II) $-(\gamma \text { ECG-OEt })_{2}$ complex were 14 and 6, respectively. Each restraint included restrictions for four distances (two intramonomeric and two intermonomeric) in the simultaneous application of average distances (type SUM using XPLOR software). ${ }^{41}$ This fact stems from the symmetry of complexes studied. The restraints enforcing the equivalence of both monomeric units of complexes were additionally included for every NOE. Harmonic distance restraints were applied for bonds connecting the $\mathrm{Zn}$ (II) ion and its four donor atoms provided by GSSG or $(\gamma \mathrm{ECG}-$ $\mathrm{OEt})_{2}$. One should emphasize the fact that no restraints between water molecules and GSSG or $(\gamma \text { ECG-OEt })_{2}$ were included in the calculations. Two further dihedral angle restraints were added for $\chi_{1}$ dihedrals of Cys residues. The $\chi_{1}$ dihedral governs the values of the $J_{\mathrm{AB}}$ coupling constants in the Cys residue, according to the formula given by Perez at al. ${ }^{42} \mathrm{~A}$ high value of one of these coupling constants $(11.4 \pm 0.2 \mathrm{~Hz}$ for $\mathrm{Zn}$ (II) - GSSG and $10.7 \pm 0.2$ for $\left.\mathrm{Zn}(\mathrm{II})-(\gamma \mathrm{ECG}-\mathrm{OEt})_{2}\right)$ and a small value of the second one $(4.3 \pm 0.2 \mathrm{~Hz}$ and $4.2 \pm 0.2 \mathrm{~Hz}$, respectively), together limited the $\chi_{1}$ value to the regions around either -60 or $+180^{\circ}$. Six-hundred conformations were calculated for each complex using a simulated annealing procedure with square-well potential constraints included, 300 with $\chi_{1}=$ 180 and 300 with $\chi_{1}=-60$. The initial structure was minimized

(36) Gottlieb, H. E.; Kotlyar, V.; Nudelman, A. J. Org. Chem. 1997, 62, $7512-7515$.

(37) Bothner-By, A. A.; Stephens, R. L.; Lee, J.-M.; Warren, C. D.; Jeanloz, R. W. J. Am. Chem. Soc. 1984, 106, 811-813.

(38) Bax, A.; Davis, D. G. J. Magn. Reson. 1985, 63, 207-213.

(39) Kay, L. E.; Keifer, P.; Saarinen, T. J. Am. Chem. Soc. 1992, 114, 10663-10665.

(40) Kontaxis, G.; Stonehouse, J.; Laue, E. D.; Keeler, J. J. Magn. Reson., Ser. A 1994, 111, 70-76.

(41) Brünger,A. T. X-PLOR, a System for X-ray Crystallography and NMR; Yale University Press: New Haven, CT, 1992.

(42) Pérez, C.; Löhr, F.; Rüterjans, H.; Schmidt, J. M. J. Am. Chem. Soc. 2001, 123, 7081-7093. with only harmonic restraints applied on distances between $\mathrm{Zn}(\mathrm{II})$ and its four donor atoms. Then, $30 \mathrm{ps}$ of high-temperature $(1000 \mathrm{~K})$ molecular dynamics was performed, followed by a process of cooling down to $100 \mathrm{~K}$ over $6 \mathrm{ps}$, and by a potential energy minimization. The resulting structures were refined ( 20 ps dynamics at $300 \mathrm{~K}$ ) and minimized. During the annealing and refinement procedure, all restraints were applied. The full Lennard-Jones potential and distance-scaled electrostatic interactions were used in this refinement. The 30 lowest energy structures were analyzed and subdivided into families. The maximum backbone RMSD between any two members of one family was set to $0.5 \AA$. The VMD 1.8 .1 software was used for structure visualization. ${ }^{43}$

Fluorimetry. The $\mathrm{Zn}(\mathrm{II})$ competition between the $\mathrm{Zn}(\mathrm{II})$ sensitive fluorescent chelating sensor FluoZin-3 was studied by fluorescence changes using Jasco FP 750 spectrofluorometrat $25{ }^{\circ} \mathrm{C} .{ }^{44}$ Samples containing $0.1 \mu \mathrm{M}$ FluoZin-3 tetrapotassium and $0.05 \mu \mathrm{M} \mathrm{ZnSO}_{4}$ in a $50 \mathrm{mM}$ HEPES buffer $(\mathrm{pH}=7.4, I=$ $0.1 \mathrm{M}$ from $\mathrm{KNO}_{3}$ ) were titrated either with a $30 \mathrm{mM}$ or with a $300 \mathrm{mM}$ solution of GSSG in fluorimeter quartz cuvettes $(1 \mathrm{~cm}$ $\times 1 \mathrm{~cm}$ ) followed by $5 \mathrm{~min}$ of equilibration. Relative changes of the $\mathrm{Zn}(\mathrm{II})-$ FluoZin-3 complex concentration were monitored by fluorescence measurements $(F)$. These data were used for determination of the exact FluoZin-3 concentration and for calculations of competition equilibria between FluoZin-3 and GSSG. The fluorescent complex was excited at $492 \mathrm{~nm}$ and measured in the range of $495-600 \mathrm{~nm}$ (maximum emission at $517 \mathrm{~nm})$. Concentration of free zinc $\left(\left[\mathrm{Zn}^{2+}\right]\right)$ was calculated as described previously by independent calibration of fluorescence in the presence of $\mathrm{ZnSO}_{4}$ excess $\left(F_{\max }\right)$ and EDTA $\left(F_{\min }\right)$ according to the formula $\left[\mathrm{Zn}^{2+}\right]=K_{\mathrm{d}} \times\left(F-F_{\min }\right) /\left(F_{\max }-\right.$ $\left.F_{\min }\right) . K_{\mathrm{d}}$ is a dissociation constant $(8.9 \mathrm{nM})$ of the $\mathrm{Zn}$ (II)-FluoZin-3 complex measured under the same conditions used here (50 mM HEPES buffer, $\mathrm{pH}=7.4, I=0.1 \mathrm{M}) .^{9,44,45}$

\section{Results}

Acid-Base Properties of GSSG and Its Analogs. Protonation constants of GSSG (Scheme 1) were obtained by potentiometry at four temperature values, 19, 25, 30, and $37{ }^{\circ} \mathrm{C}$, to enable calculations of thermochemical parameters of protonation phenomena. These constants are presented in Table 1 and are in good agreement with the previous determinations at $25^{\circ} \mathrm{C}^{27,46-48}$ and at $37^{\circ} \mathrm{C}$. 49,50 The constants determined at $25{ }^{\circ} \mathrm{C}$ were published previously in our study on $\mathrm{Ni}$ (II) complexes of GSNO and GSSG. ${ }^{51}$ A reliable determination of the sixth most acidic constant by potentiometry was impossible under our experimental conditions. Several potentiometric determinations of this constant were published at 25 and $37^{\circ} \mathrm{C} .^{27,47,52-54}$ The broad range of values obtained, from

(43) Humphrey, W.; Dalke, A.; Schulten, K. J. Mol. Graphics 1996, 14, 33-38.

(44) Krẹżel, A.; Maret, W. J. Am. Chem. Soc. 2007, 129, 10911-10921. (45) Pomorski, A.; Otlewski, J.; Krężel, A. ChemBioChem 2010, 11, 1214 1218.

(46) Theriault, Y.; Cheesman, B. V.; Arnold, A. P.; Rabenstein, D. L. Can. J. Chem. 1984, 62, 1312-1319.

(47) Noszal, B.; Szakacs, Z. J. Phys. Chem. B 2003, 107, 5074-5080.

(48) Piu, P.; Sanna, G.; Zoroddu, M. A.; Seeber, R.; Basosi, R.; Pogni, R. J. Chem. Soc., Dalton Trans. 1995, 1267-1271.

(49) Micheloni, M.; May, P. M.; Williams, D. J. Inorg. Nucl. Chem. 1978, 40, 1209-1219.

(50) Formicka-Kozłowska, G.; Kozłowski, H.; Jeżowska-Trzebiatowska,

B. Acta Biochim. Pol. 1979, 26, 239-248.

(51) Kreżel, A.; Bal, W. Chem. Res. Toxicol. 2004, 17, 392-403.

(52) Powell, K. J.; Town, R. M. Austral. J. Chem. 1995, 48, 1039-1044.

(53) Shtyrlin, V. G.; Zyavkina, Y. I.; Ilakin, V. S.; Garipov, R. R.;

Zakharov, A. V. J. Inorg. Biochem. 2005, 99, 1335-1346.

(54) Pessoa, J. C.; Tomas, I.; Kiss, T.; Buglyo, P. J. Inorg. Biochem. 2001, $84,259-270$. 
Table 1. Thermodynamic Description of GSSG Protonation at $I=0.1 \mathrm{M}\left(\mathrm{KNO}_{3}\right)^{a}$

\begin{tabular}{|c|c|c|c|c|c|c|c|c|c|c|}
\hline \multirow[b]{2}{*}{ species } & \multirow[b]{2}{*}{ reaction } & \multicolumn{4}{|c|}{$\log \beta_{\mathrm{i}}^{b}$} & \multicolumn{2}{|c|}{$\mathrm{p} K_{\mathrm{a}}$ at $25^{\circ} \mathrm{C}$} & \multicolumn{3}{|c|}{ thermochemical constants ${ }^{c}$} \\
\hline & & $19^{\circ} \mathrm{C}$ & $25^{\circ} \mathrm{C}$ & $30{ }^{\circ} \mathrm{C}$ & $37^{\circ} \mathrm{C}$ & potentiometry & $\mathrm{NMR}^{d}$ & $-\Delta H^{e}$ & $\Delta S^{f}$ & $-\Delta G^{e}$ \\
\hline$\overline{\mathrm{HL}^{3-}}$ & $K_{1}, \mathrm{HL}^{3-} \leftrightarrows \mathrm{L}^{4-}+\mathrm{H}^{+}$ & $9.831(6)$ & $9.695(4)$ & $9.552(3)$ & $9.459(4)$ & 9.695 & $9.71(4)$ & $37(4)$ & $63(12)$ & $55.35(2)$ \\
\hline $\mathrm{H}_{2} \mathrm{~L}^{2-}$ & $K_{2}, \mathrm{H}_{2} \mathrm{~L}^{2-} \leftrightarrows \mathrm{HL}^{3-}+\mathrm{H}^{+}$ & $18.806(5)$ & $18.583(4)$ & $18.340(3)$ & $18.086(4)$ & 8.888 & $8.81(4)$ & $34(3)$ & $56(10)$ & $50.74(2)$ \\
\hline $\mathrm{H}_{3} \mathrm{~L}^{-}$ & $K_{3}, \mathrm{H}_{3} \mathrm{~L}^{-} \leftrightarrows \mathrm{H}_{2} \mathrm{~L}^{2-}+\mathrm{H}^{+}$ & $22.685(9)$ & $22.524(6)$ & $22.320(5)$ & $22.103(6)$ & 3.941 & $3.96(2)$ & $-13(1)$ & $119(4)$ & $22.50(3)$ \\
\hline $\mathrm{H}_{4} \mathrm{~L}$ & $K_{4}, \mathrm{H}_{4} \mathrm{~L} \leftrightarrows \mathrm{H}_{3} \mathrm{~L}^{-}+\mathrm{H}^{+}$ & $25.81(1)$ & $25.690(7)$ & $25.500(6)$ & $25.303(8)$ & 3.165 & $3.14(2)$ & $-7(1)$ & $85(4)$ & $18.07(4)$ \\
\hline $\mathrm{H}_{5} \mathrm{~L}^{+}$ & $K_{5}, \mathrm{H}_{5} \mathrm{~L}^{+} \leftrightarrows \mathrm{H}_{4} \mathrm{~L}+\mathrm{H}^{+}$ & $28.00(2)$ & $28.10(1)$ & $28.088(7)$ & $28.10(1)$ & 2.409 & $2.40(2)$ & $-59(1)$ & $243(4)$ & $13.75(6)$ \\
\hline $\mathrm{H}_{6} \mathrm{~L}^{2+}$ & $K_{6}, \mathrm{H}_{6} \mathrm{~L}^{2+} \leftrightarrows \mathrm{H}_{5} \mathrm{~L}^{+}+\mathrm{H}^{+}$ & $29.39^{g}$ & $29.71^{g}$ & $29.88^{g}$ & $30.10^{g}$ & $1.61^{g}$ & $1.51(2)$ & $-59^{g}$ & $229^{g}$ & $9.2^{g}$ \\
\hline
\end{tabular}

${ }^{a}$ Statistical errors of constant determinations are given in parentheses. ${ }^{b} \beta_{\mathrm{i}}=\left[\mathrm{H}_{\mathrm{i}} \mathrm{L}\right] /\left([\mathrm{L}]\left[\mathrm{H}^{+}\right]^{\mathrm{i}}\right) .{ }^{c}$ Calculated for individual protonation reactions at $25^{\circ} \mathrm{C}$, using potentiometric values of $\mathrm{p} K_{\mathrm{a}}$ and their temperature dependencies. ${ }^{d}$ Measured in $\mathrm{D}_{2} \mathrm{O}$ and $I \sim 0.01$, and recalculated. ${ }^{47 e}$ Units are kilojoules per mol $\left(\mathrm{kJ} \mathrm{mol}^{-1}\right) \cdot{ }^{f}$ Units are joules per Kelvin per mol $\left(\mathrm{J} \mathrm{K}^{-1} \mathrm{~mol}^{-1}\right){ }^{g}$ Beyond the measurement range, extrapolated on the basis of statistical considerations (see text).

1.60 to $2.34,{ }^{48,52,55}$ corresponds to a low reliability of potentiometric determination of this constant, as pointed out previously. ${ }^{53}$

NMR provided an alternative method of establishing all protonation constants of GSSG, including the most acidic one. ${ }^{56,57}$ However, NMR titrations provide data on the acidities of individual groups, rather than overall dissociation constants, produced by potentiometry. To convert the former (Supporting Information Table S1) to the latter, one can use a range normalization function (eq 1) where $p$ and $u$ indexes indicate protonated and unprotonated states, respectively.

$$
F=\left(\delta-\delta_{\mathrm{p}}\right) /\left(\delta_{\mathrm{u}}-\delta_{\mathrm{p}}\right)
$$

This function was constructed for chemical shifts of $\alpha$ Glu (separately in low and high $\mathrm{pH}$ ) and Gly protons (only low $\mathrm{pH}$ ) and fitted to eq 2, valid for two overlapping protonation processes. ${ }^{58,59}$

$$
F=\frac{10^{\mathrm{pH}-\mathrm{p} K_{1}}+2 \times 10^{2 \times \mathrm{pH}-\left(\mathrm{p} K_{1}+\mathrm{p} K_{2}\right)}}{1+10^{\mathrm{pH}-\mathrm{p} K_{1}}+10^{2 \times \mathrm{pH}-\left(\mathrm{p} K_{1}+\mathrm{p} K_{2}\right)}}
$$

Protonation constants established for GSSG by potentiometry and NMR are included in Table 1. The assignment of ${ }^{1} \mathrm{H}$ and ${ }^{13} \mathrm{C}$ NMR spectra of GSSG, based on homo- and heteronuclear correlation spectra, was in agreement with the literature. ${ }^{29,60}$ The match between the NMR and potentiometry-derived values is excellent, as presented in Figure 1, on which the NMR titration curves are overlaid on the protonic species distribution derived from potentiometric data.

A more detailed analysis of dependence of chemical shifts on $\mathrm{pH}$ revealed a specific sensitivity of the Gly protons to the amine deprotonation, shown in Figure 2. The Cys protons did not show such dependence, although they are located much closer to the amine residues in the peptide sequence. The corresponding $\mathrm{p} K$ values are provided in Supporting Information Table S1.

The thermochemical parameters of GSSG protonation reactions are presented in Table 1 as well. These reversible reactions were defined as association processes to make

(55) Palmer, A. G., III; Cavanagh, J.; Wright, P. E.; Rance, M. J. Magn. Reson. 1991, 93, 151-170.

(56) Kreżel, A.; Bal, W. J. Inorg. Biochem. 2004, 98, 161-166.

(57) Rabenstein, D. L.; Sayer, T. L. Anal. Chem. 1976, 48, 1141-1146.

(58) Krężel, A.; Szczepanik, W.; Świątek, M.; Jeżowska-Bojczuk, M. Bioorg. Med. Chem. 2004, 12, 4075-4080.

(59) Dorčák, V.; Krȩżel, A. Dalton Trans. 2003, 2253-2259.

(60) Krȩżel, A.; Wójcik, J.; Maciejczyk, M.; Bal, W. Chem. Commun. (Camb.) 2003, 704-705.

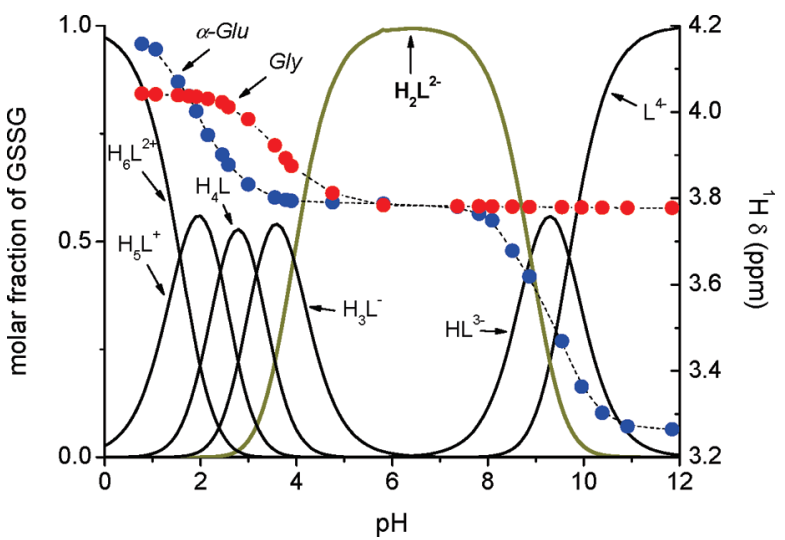

Figure 1. A comparison of the potentiometry derived species distribution of protonic species of GSSG at $25^{\circ} \mathrm{C}$ and $I=0.1\left(\mathrm{KNO}_{3}\right)$ with $\mathrm{pH}$ dependencies of chemical shifts of nonexchangeable protons specific to $K_{1}, K_{2}, K_{5}$, and $K_{6}\left(\alpha-\mathrm{Glu}\right.$, blue circles) and to $K_{3}$ and $K_{4}$ (Gly, red circles). Protonation reactions assigned according to Table 1 . The thick dark yellow line represents the main species $\mathrm{H}_{2} \mathrm{~L}^{2-}$ presented at physiological $\mathrm{pH}$, which contains four deprotonated carboxyl groups.
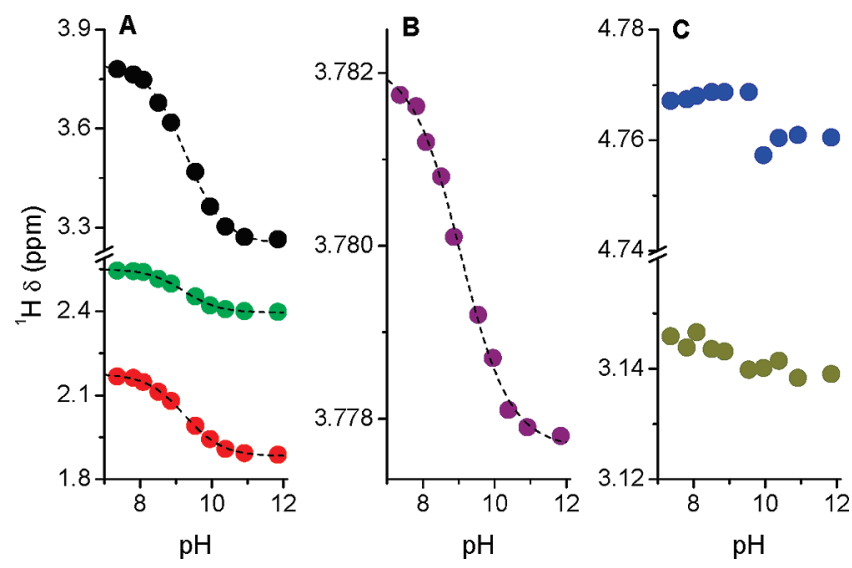

Figure 2. A comparison of $\mathrm{pH}$ dependencies of chemical shifts of nonexchangeable protons of $\mathrm{GSSG}\left(10 \mathrm{mM}, 25^{\circ} \mathrm{C}\right)$ in the alkaline $\mathrm{pH}$ range, underlining similarities between profiles for Glu (A) and Gly (B) protons, as opposed to Cys protons (C). Individual protons are color-coded as follows: $\alpha$-Glu (black), average of $\beta$-Glu (red), $\gamma$-Glu (green), average of Gly (purple), $\alpha$-Cys (blue), average of $\beta$-Cys (dark yellow).

the sign of $\Delta G$ negative. The $\Delta H$ and $\Delta S$ values were calculated from linear relationships $\ln K_{\mathrm{i}}(\mathrm{T})$.

The protonation equilibria of analogs and derivatives of GSSG were studied by potentiometry at $25^{\circ} \mathrm{C}$. All constants obtained are presented in Table 2. 
Table 2. Cumulative Protonation Constants $\left(\log \beta_{\mathrm{i}}\right.$ Values ${ }^{a}$ for Derivatives and Analogs of GSSG at $T=25^{\circ} \mathrm{C}, I=0.1 \mathrm{M}\left(\mathrm{KNO}_{3}\right)^{b}$

\begin{tabular}{|c|c|c|c|c|c|c|}
\hline peptide & HA & $\mathrm{H}_{2} \mathrm{~A}$ & $\mathrm{H}_{3} \mathrm{~A}$ & $\mathrm{H}_{4} \mathrm{~A}$ & $\mathrm{H}_{5} \mathrm{~A}$ & $\mathrm{H}_{6} \mathrm{~A}$ \\
\hline \multicolumn{7}{|c|}{ tripeptide disulfides } \\
\hline $\begin{array}{l}(\gamma \mathrm{ECS})_{2} \\
(\gamma \mathrm{ECE})_{2}{ }^{c} \\
\left(\gamma \mathrm{ECG}-\mathrm{NH}_{2}\right)_{2} \\
(\gamma \mathrm{ECG}-\mathrm{OEt})_{2} \\
(\gamma \mathrm{EcG})_{2}\end{array}$ & $\begin{array}{l}9.75(1) \\
9.912(7) \\
9.426(8) \\
9.564(9) \\
9.72(1)\end{array}$ & $\begin{array}{l}18.43(1) \\
18.878(7) \\
18.117(7) \\
18.305(8) \\
18.51(1)\end{array}$ & $\begin{array}{l}22.14(2) \\
23.99(1) \\
20.77(1) \\
21.04(2) \\
22.45(3)\end{array}$ & $\begin{array}{l}24.73(2) \\
28.25(1) \\
c \\
c \\
25.78(3)\end{array}$ & $\begin{array}{l}26.62(5) \\
31.73(1) \\
28.34(4)\end{array}$ & $\begin{array}{l}c \\
34.40(2)\end{array}$ \\
\hline \multicolumn{7}{|c|}{ dipeptide disulfides } \\
\hline $\begin{array}{l}(\gamma \mathrm{EC})_{2} \\
(\gamma \mathrm{EC}-\mathrm{OEt})_{2}\end{array}$ & $\begin{array}{l}9.799(3) \\
9.604(5)\end{array}$ & $\begin{array}{l}18.772(7) \\
18.358(5)\end{array}$ & $\begin{array}{l}22.05(1) \\
20.81(2)\end{array}$ & $\begin{array}{l}23.42(9) \\
c\end{array}$ & & $c$ \\
\hline \multicolumn{7}{|c|}{ mixed disulfides } \\
\hline $\begin{array}{l}\gamma \mathrm{ECG}-\gamma \mathrm{EC} \\
\gamma \mathrm{ECG}-\gamma \mathrm{EC}-\mathrm{OEt}\end{array}$ & $\begin{array}{l}9.76(1) \\
9.65(1)\end{array}$ & $\begin{array}{l}18.66(1) \\
18.47(1)\end{array}$ & $\begin{array}{l}22.53(2) \\
21.82(2)\end{array}$ & $\begin{array}{l}25.26(3) \\
24.17(6)\end{array}$ & $\begin{array}{l}27.68(6) \\
c\end{array}$ & $c$ \\
\hline \multicolumn{7}{|c|}{ other } \\
\hline $\begin{array}{l}\mathrm{S}-\mathrm{MeGSH} \\
\mathrm{GSO}_{3} \mathrm{H} \\
\mathrm{Glu}\end{array}$ & $\begin{array}{l}9.124(3) \\
9.284(2) \\
9.588(7)\end{array}$ & $\begin{array}{l}12.682(5) \\
12.842(4) \\
13.790(7)\end{array}$ & $\begin{array}{l}14.66(2) \\
14.76(3) \\
16.00(2)\end{array}$ & & & \\
\hline
\end{tabular}

Table 3. Cumulative Stability Constants for Zn(II) Complexes with GSSG at $I=0.1 \mathrm{M}\left(\mathrm{KNO}_{3}\right)$ and Various Temperatures ${ }^{a}$

\begin{tabular}{lcccc}
\hline & \multicolumn{4}{c}{$\log \beta_{\mathrm{ijk}}{ }^{b}$} \\
\cline { 2 - 5 } species & $19{ }^{\circ} \mathrm{C}$ & $25^{\circ} \mathrm{C}$ & $30{ }^{\circ} \mathrm{C}$ & $37{ }^{\circ} \mathrm{C}$ \\
\hline $\mathrm{ZnHL}^{-}$ & $14.24(4)$ & $14.19(8)$ & $14.08(2)$ & $14.03(5)$ \\
$\mathrm{ZnL}^{2-}$ & $8.097(3)$ & $8.049(3)$ & $7.940(3)$ & $7.894(3)$ \\
$\mathrm{Zn}_{2} \mathrm{~L}^{3-}$ & $10.86(5)$ & $10.71(8)$ & $10.57(6)$ & $10.41(8)$ \\
$\mathrm{ZnH}_{-1} \mathrm{~L}^{3-}$ & $-1.747(6)$ & $-1.696(6)$ & $-1.674(5)$ & $-1.589(4)$
\end{tabular}

${ }^{a}$ Statistical errors of constant determinations are given in parentheses. ${ }^{b} \beta_{i j k}=\left[\mathrm{Zn}_{i} \mathrm{H}_{j} \mathrm{~L}_{k}\right] /\left([\mathrm{Zn}]^{i}\left[\mathrm{H}^{+}\right]^{j}[\mathrm{~L}]^{k}\right)$.

Thermodynamic Aspects of Zn(II) Complexation. The analysis of potentiometric titrations, performed at various temperatures, uniformly indicated the formation of four different complex species in the $\mathrm{Zn}(\mathrm{II})-\mathrm{GSSG}$ system, monomeric $\mathrm{ZnHL}^{-}, \mathrm{ZnL}^{2-}, \mathrm{ZnH}_{-1} \mathrm{~L}^{3-}$, and a bimetallic $\mathrm{Zn}_{2} \mathrm{~L}$. The stability constants for these complexes are presented in Table 3, while Table 4 presents thermodynamic constants for formal and actual $\mathrm{Zn}$ (II) binding reactions in the $\mathrm{Zn}(\mathrm{II})-\mathrm{GSSG}$ system. The $\Delta H$ and $\Delta S$ values for these reactions were calculated, as with protonation constants, from linear relationships $\ln K_{\mathrm{i}}(\mathrm{T})$.

The coordination of $\mathrm{Zn}(\mathrm{II})$ to GSSG analogs was studied only by potentiometry at $25^{\circ} \mathrm{C}$, except for the complex with $(\gamma \text { ECG-OEt })_{2}$, which was additionally studied by 2D NMR (see below). Stability constants of complexes of disulfide analogs are presented in Table 5, and those of the nondisulfide ones are given in Table 6. These tables also contain competitivity index (CI) values, which allow for a comparison of overall $\mathrm{Zn}$ (II) binding abilities of ligands forming complexes of various stoichiometries. $^{60}$

Structural Aspects of $\mathbf{Z n}($ II) Complexation. Figure 3 (left-hand panel) presents the global comparison of $\mathrm{pH}$ dependence of chemical shifts of individual GSSG protons without and with $\mathrm{Zn}(\mathrm{II})$. The signals from chemically equivalent $\beta$-Glu and $\beta$-Cys protons were averaged to
Table 4. Thermodynamic Description of Reactions of $\mathrm{Zn}(\mathrm{II})$ Complexation to GSSG at $T=25^{\circ} \mathrm{C}, I=0.1 \mathrm{M}\left(\mathrm{KNO}_{3}\right)^{a}$

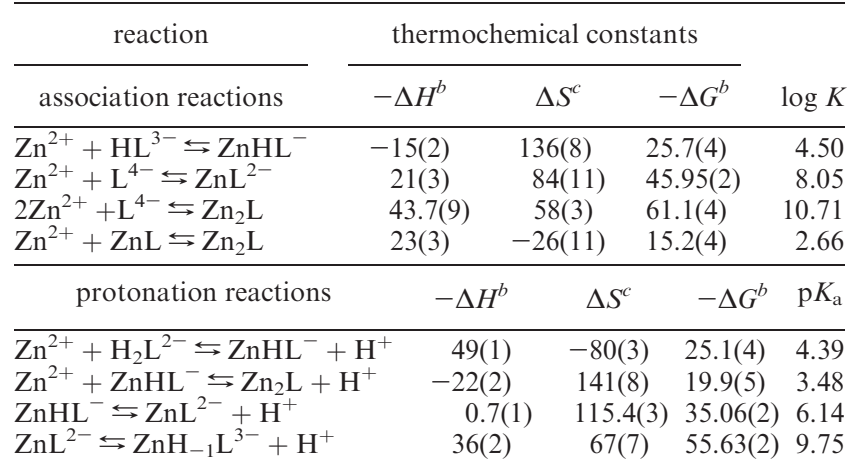

${ }^{a}$ Statistical errors of constant determinations are given in parentheses. ${ }^{b}$ Units are kilojoules per mole $\left(\mathrm{kJ} \mathrm{mol}^{-1}\right) .{ }^{c}$ Units are joules per Kelvin per mole $\left(\mathrm{J} \mathrm{K}^{-1} \mathrm{~mol}^{-1}\right)$.

simplify the presentation. The primary role of the Glu residue in $\mathrm{Zn}(\mathrm{II})$ binding at and above $\mathrm{pH} 6$ is clear. Figure 3 (right-hand panels) presents subtle effects in chemical shifts exerted by the presence of $\mathrm{Zn}(\mathrm{II})$. The complex formation removed the equivalence of $\beta$-Glu protons and increased the signal separation of $\beta$-Cys protons. Also, one of the Gly protons $\left(\mathrm{GlyH}_{1}\right)$ was specifically sensitive to $\mathrm{Zn}$ (II) binding. Figure 4 compares selected chemical shift profiles with potentiometry-based distributions of complexes at $25^{\circ} \mathrm{C}$, calculated for concentrations used in ${ }^{1} \mathrm{H}$ NMR titrations. This figure demonstrates the match between the results of these two experimental methods. One can clearly see that the $\alpha-\mathrm{Glu}$ profile reflects the formation of all four complex species, and that the $\mathrm{GlyH}_{1}$ proton is selectively sensitive to the formation of the $\mathrm{ZnL}^{2-}$ complex.

An absence of dimerization/oligomerization of the complexes at a $\mathrm{pH}^{*}$ of 8.2 , which effectively corresponds to a $\mathrm{pH}$ of $8.0^{56}$ (the $\mathrm{ZnL}^{2-}$ species predominates at ca. $90 \%$ of total $\mathrm{Zn}$ (II) under such conditions), was confirmed by the absence of changes in chemical shifts of complexed GSSG in ${ }^{1} \mathrm{H}$ NMR spectra recorded for equimolar $\mathrm{Zn}(\mathrm{II})$ and $\mathrm{GSSG}$ in the range of concentrations between $0.1 \mathrm{mM}$ and $100 \mathrm{mM}$, and in the ${ }^{13} \mathrm{C} \mathrm{NMR}$ spectra of the same samples, between $25 \mathrm{mM}$ and $100 \mathrm{mM}$ (data not shown). The ROESY spectrum of the GSSG$\mathrm{Zn}$ (II) complex was recorded with the sample containing $20 \mathrm{mM}$ GSSG and $20 \mathrm{mM} \mathrm{Zn}(\mathrm{II})$ in $\mathrm{D}_{2} \mathrm{O}$ at a $\mathrm{pH}^{*}$ of 8.4, which effectively corresponds to a $\mathrm{pH}$ of 8.2 ( $\mathrm{pH}$ chosen in such way to match the highest complex occupancy). ${ }^{56}$ This sample contained ca. $92 \%$ of the $\mathrm{ZnL}^{2-}$ species. The spectrum provided eight of nine expected intraresidual crosspeaks, as well as nine interresidual crosspeaks: three between the Glu and Cys residues, three between the Cys and Gly residues, and three between the Glu and Gly residues. The analogous ROESY spectrum was also recorded for $20 \mathrm{mM}(\gamma \mathrm{ECG}-\mathrm{OEt})_{2}$ with $20 \mathrm{mM} \mathrm{Zn}(\mathrm{II})$ at a $\mathrm{pH}^{*}$ of 8.8 , corresponding to a $\mathrm{pH}$ of $8.55,{ }^{56}$ at a maximum of $\mathrm{ZnA}$ complex formation (83\%, major contamination from the $\mathrm{Zn}_{2} \mathrm{~A}^{2+}$ species). This spectrum contained 9 of 11 expected intraresidual crosspeaks, two interresidual crosspeaks analogous to those seen for the GSSG complex and four additional interresidual crosspeaks, involving the methyl protons of the ethyl substituent on the Gly residue. The spectral assignments in the 
Table 5. Cumulative Stability Constants of Zinc Complexes of Disulfides at $T=25^{\circ} \mathrm{C}, I=0.1 \mathrm{M}\left(\mathrm{KNO}_{3}\right)^{a}$

\begin{tabular}{|c|c|c|c|c|c|c|c|}
\hline \multirow[b]{2}{*}{ peptide } & \multicolumn{5}{|c|}{$\log \beta_{i j k}^{b}$} & \multirow{2}{*}{$\frac{-\Delta G^{c}}{\mathrm{ZnA}}$} & \multirow{2}{*}{$\frac{\mathrm{CI}_{0.01 / 7.4^{d}}}{(\mathrm{GSSG} 4.22}$} \\
\hline & ZnHA & $\mathrm{ZnA}$ & $\mathrm{Zn}_{2} \mathrm{~A}$ & $\mathrm{ZnH}_{-1} \mathrm{~A}$ & $\mathrm{ZnH}_{-2} \mathrm{~A}$ & & \\
\hline \multicolumn{8}{|c|}{ tripeptide disulfides } \\
\hline$(\gamma \mathrm{ECS})_{2}$ & $13.80(1)$ & $7.75(3)$ & $10.68(1)$ & $-1.92(5)$ & & $44.2(2)$ & 4.18 \\
\hline$(\gamma \mathrm{ECE})_{2}{ }^{c}$ & $15.08(9)$ & $8.618(6)$ & $10.84(7)$ & $-1.38(2)$ & & $49.20(3)$ & 4.58 \\
\hline$\left(\gamma \mathrm{ECG}-\mathrm{NH}_{2}\right)_{2}$ & $12.7(1)$ & $7.01(3)$ & $10.57(6)$ & $-2.46(4)$ & $-11.60(3)$ & $40.0(2)$ & 3.87 \\
\hline$(\gamma \mathrm{ECG}-\mathrm{OEt})_{2}$ & $13.13(9)$ & $7.31(2)$ & $10.64(6)$ & -2.29 & & $41.7(1)$ & 4.00 \\
\hline$(\gamma \mathrm{EcG})_{2}$ & $13.78(4)$ & $7.69(1)$ & $10.67(5)$ & -1.86 & & $43.90(6)$ & 4.07 \\
\hline \multicolumn{8}{|c|}{ dipeptide disulfides } \\
\hline$(\gamma \mathrm{EC})_{2}$ & $14.46(7)$ & $8.132(4)$ & $10.79(9)$ & $-1.84(1)$ & $-11.92(4)$ & $46.42(2)$ & 4.22 \\
\hline$(\gamma \mathrm{EC}-\mathrm{OEt})$ & $13.31(5)$ & $7.43(1)$ & $10.62(7)$ & $-2.16(7)$ & & $42.42(6)$ & 4.02 \\
\hline \multicolumn{8}{|c|}{ mixed disulfides } \\
\hline$\gamma$ ECG- $\gamma$ EC & $14.31(3)$ & $8.075(8)$ & $10.77(3)$ & -1.83 & & $46.10(5)$ & 4.26 \\
\hline$\gamma$ ECG- $\gamma$ EC-OEt & $13.85(4)$ & $7.739(6)$ & 10.68(9) & -1.93 & & $44.18(3)$ & 4.15 \\
\hline
\end{tabular}

${ }^{a}$ Statistical errors of constant determinations are given in parentheses. ${ }^{b} \beta_{i j k}=\left[\mathrm{Zn}_{i} \mathrm{H}_{j} \mathrm{~L}_{k}\right] /\left([\mathrm{Zn}]^{i}\left[\mathrm{H}^{+}\right]^{j}[\mathrm{~L}]^{k}\right) .{ }^{c}$ Units are kilojoules per mol $\left(\mathrm{kJ}\right.$ mol $\left.{ }^{-1}\right)$. ${ }^{d}$ Competitivity index calculated for $\mathrm{pH} 7.4$ and disulfide $\mathrm{L}, \mathrm{Zn}(\mathrm{II})$ and $\mathrm{Z}$ concentrations of $0.01 \mathrm{M}$. CI $\mathrm{I}_{0.01 / 7.4}$ is $\log K_{\mathrm{MZ}}$ fulfilling the condition $\Sigma_{i j k}\left(\left[\mathrm{Zn}_{i} \mathrm{H}_{j} \mathrm{~L}_{k}\right]=[\mathrm{ZnZ}]^{60}\right.$

Table 6. Cumulative Stability Constants of Zinc Complexes of Non-Disulfide Analogs at $T=25^{\circ} \mathrm{C}, I=0.1 \mathrm{M}\left(\mathrm{KNO}_{3}\right)^{a}$

\begin{tabular}{lccrrrc}
\hline & \multicolumn{4}{c}{$\log \beta_{i j k}{ }^{a}$} & & $\mathrm{CI}_{0.01 / 7.4}{ }^{b}$ \\
\cline { 2 - 4 } compound & $\mathrm{ZnA}$ & $\mathrm{ZnA}_{2}$ & \multicolumn{1}{c}{$\mathrm{ZnH}_{-1} \mathrm{~A}_{2}$} & $\mathrm{ZnH}_{-2} \mathrm{~A}_{2}$ & & $(\mathrm{GSSG} 4.22)$ \\
\hline $\mathrm{S}-\mathrm{Me}-\mathrm{GSH}$ & $4.63(2)$ & $8.43(3)$ & $-0.48(2)$ & $-10.12(2)$ & 2.94 \\
$\mathrm{GSO}_{3} \mathrm{H}$ & $4.73(3)$ & $8.75(3)$ & $0.01(2)$ & $-9.84(2)$ & 2.88 \\
Glu & $4.83(2)$ & $9.04(2)$ & $-0.43(3)$ & $-10.84(3)$ & & 2.69
\end{tabular}

${ }^{a}$ Statistical errors of constant determinations are given in parentheses. ${ }^{b} \beta_{i j k}=\left[\mathrm{Zn}_{i} \mathrm{H}_{j} \mathrm{~L}_{k}\right] /\left([\mathrm{Zn}]^{i}\left[\mathrm{H}^{+}\right]^{j}[\mathrm{~L}]^{k}\right)$.

ROESY spectra are presented in Supporting Information Table S2, while the lists of nondiagonal crosspeaks, together with their integrals, are presented in Supporting Information Table S3.

The molecular mechanics calculations of the structures of $\mathrm{ZnL}^{2-}$ and $\mathrm{ZnA}$ species from the above NMR data were based on the following assumptions regarding their structures: (i) The $\mathrm{Zn}$ (II) ion is coordinated to amino and carboxylate donors of both Glu residues, set in four adjacent corners of an octahedron. The $\mathrm{Zn}-\mathrm{N}$ distances were set at $0.2103 \mathrm{~nm}$, the $\mathrm{Zn}-\mathrm{O}$ distances were set at $0.2036 \mathrm{~nm}$, and the carboxylate groups were positioned as monodentate donors. These distances and arrangements were based on the X-ray structure of the $\mathrm{Zn}$ (II)-Glu complex. $^{61}$ (ii) Two additional water molecules were coordinated in the remaining two octahedral positions around $\mathrm{Zn}(\mathrm{II})$. The $\mathrm{Zn}-\mathrm{O}$ (water) distances were set at $0.207 \mathrm{~nm} .{ }^{61}$ (iii) The C2 symmetry for both molecules was forced by distance symmetry restraints implemented in the XPLOR program. ${ }^{41}$

The 30 lowest energy conformers of $\mathrm{Zn}(\mathrm{II})-\mathrm{GSSG}$, yielded by calculations, were divided into six families. The application of the criterion of -60 or $+180^{\circ}$ for the $\chi_{1}$ angle of Cys, based on extreme values of measured ${ }^{3} J_{\mathrm{H} \alpha \mathrm{H} \beta}$ couplings (11.4 and $4.3 \mathrm{~Hz}$ ) for this residue, eliminated three of these families. Structures of the lowest energy members of each of three remaining families are shown in Figure 5. The conformational properties and mean energies

(61) Gramaccioli, C. M. Acta Crystallogr. 1966, 21, 600-605.
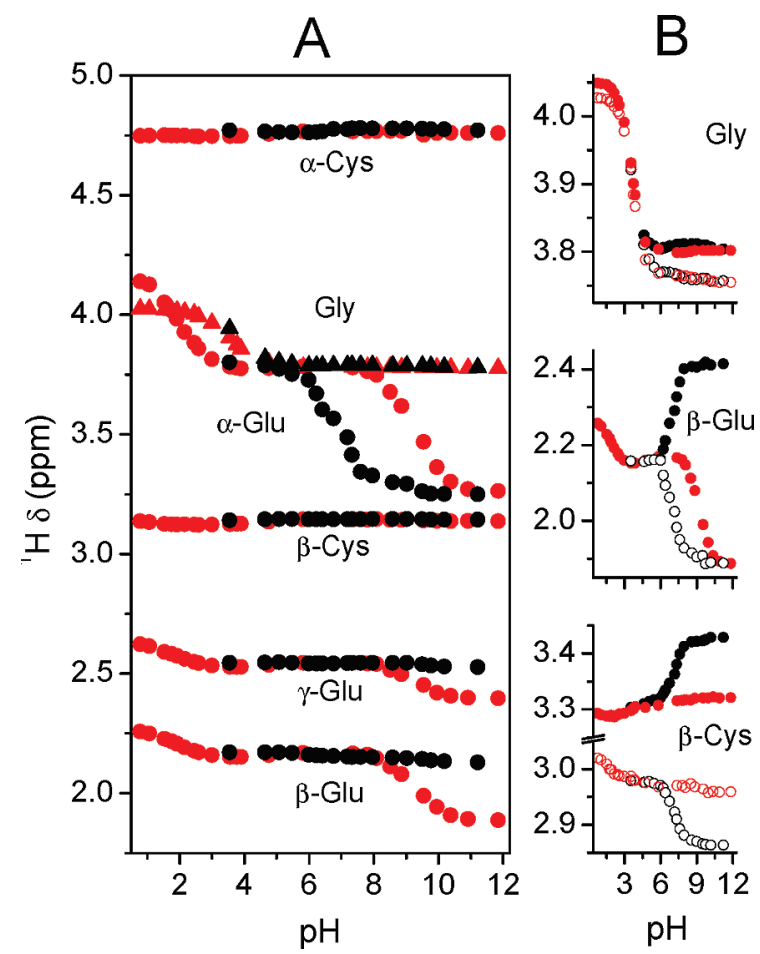

Figure 3. A global comparison of $\mathrm{pH}$ dependencies of chemical shifts in free GSSG (red symbols) and Zn(II)-complexed GSSG (black symbols). Concentrations of GSSG and $\mathrm{Zn}$ (II) were $10 \mathrm{mM}$; the spectra were recorded at $25{ }^{\circ} \mathrm{C}$. In panel $\mathrm{A}$, the chemical shifts for individual $\mathrm{CH}_{2}$ groups are averaged, while in panel B they are shown separately for nondegenerate cases of $\beta$-Glu (for Zn(II)-complexed GSSG only), $\beta$-Cys, and Gly protons: $\square, \mathbf{\square}, \mathrm{H}_{1} ; \mathrm{O}, \boldsymbol{\bullet}, \mathrm{H}_{2}$ (assignments arbitrary).

of these families are presented in Supporting Information Table S4. One can observe two types of coordination patterns in calculated structures, which are labeled trans$N$ (trans with respect to amine donors-family 1) and trans- $W$ (trans with respect to water molecules-families 2 and 3). They are shown at the bottom of Figure 5. Each structure is stabilized by two pairs of hydrogen bonds. The dihedral angle of the disulfide bridge assumes an energetically optimal value of $-90^{\circ}$ for family 1 . In the 
remaining two families, the deviations of values of this dihedral angle from the optimum value of $90^{\circ}$ (second symmetric minimum) are at least $20^{\circ}$. In family 1 , the backbone dihedral of Cys is placed in the helical region (third quadrant) of the Ramachandran plot. In family 3 , this dihedral falls into the $\beta$ structure region and, in family 2 , into the forbidden fourth quadrant $(\varphi>0)$. The structural properties presented above, together with a large mean energy difference between the first and the remaining two families, strongly suggest that a "true" structure belongs to family 1 .

The 30 lowest energy conformers for $\mathrm{Zn}(\mathrm{II})-(\gamma \mathrm{ECG}-$ $\mathrm{OEt})_{2}$ yielded by calculations had to be divided into as many as 12 families. Applying a similar procedure to that described above for $\mathrm{Zn}(\mathrm{II})-\mathrm{GSSG}$ with a somewhat broader criterion (the value of measured ${ }^{3} J_{\mathrm{H} \alpha \mathrm{H} \beta}$ coupling was here a little smaller, $-10.7 \mathrm{~Hz}$ ) allowed to discard five of the families. Structural properties of the lowest energy members of the remaining seven families and their mean

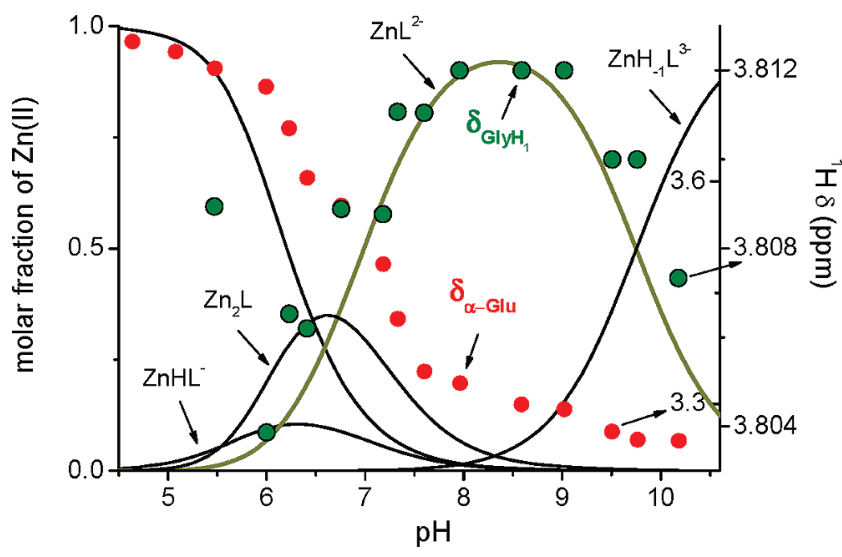

Figure 4. The species distribution for $\mathrm{Zn}$ (II) - GSSG complexes, calculated for the conditions of NMR experiments $(10 \mathrm{mM}$ GSSG, $10 \mathrm{mM}$ $\mathrm{Zn}(\mathrm{II}), 25^{\circ} \mathrm{C}$ ). Chemical shifts of $\alpha$-Glu (red circles) and $\mathrm{GlyH}_{1}$ (olive circles) are overlaid for comparison. The thick dark yellow line indicates the main species $\mathrm{ZnL}^{2-}\left([\mathrm{Zn}-\mathrm{GSSG}]^{2-}\right)$ present at physiological $\mathrm{pH}$. energies are presented in Supporting Information Table S5. The lowest energy members of these superfamilies are shown in Supporting Information Figure S1. This result suggests that $\mathrm{Zn}(\mathrm{II})-(\gamma \mathrm{ECG}-\mathrm{OEt})_{2}$ complexes in solution exist in a conformational equilibrium between open and closed structures.

\section{Discussion}

Protonation equilibria. Values of protonation macroconstants of GSSG, as mentioned above, agree well with those determined previously. ${ }^{27,46,47,52,54}$ The value of $\mathrm{p} K_{6}$, determined by NMR, is in excellent agreement with the most recent reports. ${ }^{47,54}$ This value is lower than a practical acidic limit for determinations using $\mathrm{pH}$-metric titrations of millimolar compounds, ca. 2.0. Errors in previous $\mathrm{pH}$-metric determinations of this constant $\mathrm{t}^{27,52}$ were most likely caused by ignoring this fact, as pointed out previously. ${ }^{53}$

We have confined our analysis of GSSG protonation to macroconstants, because this level of analysis is sufficient as a background for the study of $\mathrm{Zn}$ (II) complex formation, our main goal. Also, the macroconstants determined in the present work agree well with the results of a recent detailed study of GSSG microspeciation. ${ }^{47}$ However, enthalpies and entropies related to GSSG protonation were not reported previously and therefore require a brief discussion. These thermodynamic parameters describing protonation processes in peptides at moderate ionic strengths were previously obtained mostly for dipeptides, such as those composed of glycine and alanine. ${ }^{62,63}$ The tripeptide triglycine was also studied. ${ }^{63}$ These studies provide a suitable reference for the discussion of the C-terminal carboxylate in GSSG. In turn, thermochemical studies of protonation of simple amino acids, such as glycine, provide a reference for the $\gamma$-Glu moiety. ${ }^{64-66}$ In another thermochemical study, protonation of GSH and triglycine was investigated at a high ionic strength of $3 \mathrm{M} \mathrm{NaClO}_{4}{ }^{67}$

The deprotonation of a terminal carboxylic group in simple di- and tripeptides is accompanied by small enthalpic

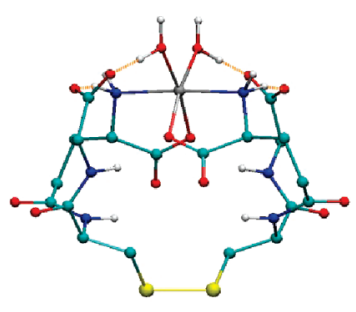

Family 1

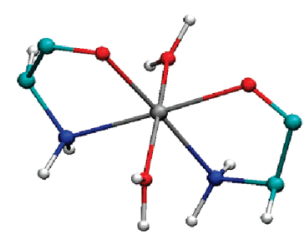

trans W

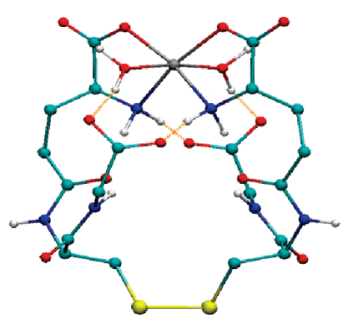

Family 2

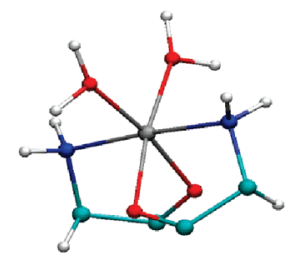

trans $\mathrm{N}$

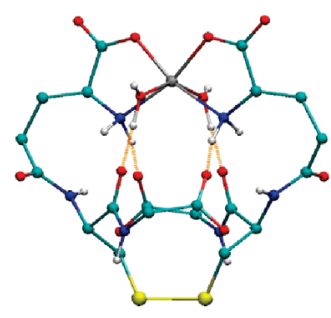

Family 3

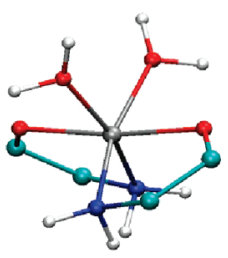

trans $\mathrm{O}$

Figure 5. Three types of coordination patterns. trans-W, waters in trans position; trans- $\mathrm{N}$, amine nitrogens in trans position; trans-O, carboxyl oxygens in trans positions (lower row) and the lowest energy members of three families of the $\mathrm{Zn}(\mathrm{II})-\mathrm{GSSG}$ complex (upper row). Hydrogen bonds are shown in orange. 
effects, typically less than $10 \mathrm{~kJ} \mathrm{~mol}^{-1}$, together with sizable entropic contributions $\left(40-70 \mathrm{~J} \mathrm{~mol}^{-1} \mathrm{~K}^{-1}\right){ }^{62,63}$ Glycine carboxylate protonation reactions involve similarly low $\Delta H$ values, with $\Delta S$ about $30 \mathrm{~J} \mathrm{~mol}^{-1} \mathrm{~K}^{-1}$. $56-60$ The $\alpha$-amine protonation is controlled primarily by enthalpy $\left(40-50 \mathrm{~kJ} \mathrm{~mol}^{-1}\right)$, with little entropy change (usually less than $10 \mathrm{~J} \mathrm{~mol}^{-1} \mathrm{~K}^{-1}$ ). ${ }^{62,63} \mathrm{In}$ turn, entropic effects are significant for the amine of the Glu moiety in GSH, and in glycine, with $\Delta S$ values of $40-60 \mathrm{~J} \mathrm{~mol}^{-1}$ $\mathrm{K}^{-1} \cdot{ }^{64-67}$ This difference is due to a salt bridge formation between the deprotonated carboxylate and the neighboring protonated amine in $\alpha$-amino acid moieties. The protonation of GSSG amines (top two lines in Table 1) fits in this pattern, with significant $\Delta H$ and $\Delta S$ contributions. The thermodynamics of the Gly residue protonations is similar to the dipeptide and tripeptide data, although the enthalpic contribution to the free energy is slightly negative and is accompanied by higher entropic contributions (two middle lines in Table 1). The major difference with simple models is demonstrated by the protonation of a Glu carboxylate $\left(\mathrm{H}_{4} \mathrm{~L}+\mathrm{H}^{+} \leftrightarrows \mathrm{H}_{5} \mathrm{~L}^{+}\right)$. It involves a very high negative enthalpy, compensated by a very large entropy change, nearly 10 -fold higher from that determined for simple amino acids. The explanation of this effect is provided by the crystal structure of the $\mathrm{H}_{4} \mathrm{~L}$ species of GSSG, ${ }^{68}$ which indicates additional salt bridges between the $\mathrm{COO}^{-}$and $\mathrm{NH}_{3}^{+}$groups belonging to different Glu moieties. A disorganization of this longrange structuring is entropically favorable. Also, the crystal of GSSG contains four ordered water molecules. Two of them are located within the salt-bridged macrochelate loop, composed of the two Glu and two Cys residues. The commercial polycrystalline GSSG samples contain one water molecule per GSSG. It is therefore reasonable to assume that one or two water molecules remain bonded to GSSG after dissolution, and their release contributes to both a decrease of enthalpy and an increase of entropy accompanying the protonation of the $\mathrm{H}_{4} \mathrm{~L}$ species of GSSG.

Solution Structures of Uncomplexed Disulfides. The comparison of GSSG with its analogs demonstrated a dependence of values of amine protonation constants on electronic charges on their $\mathrm{C}$-terminal residues, $z_{\mathrm{C}}$. We observed such an effect previously in a corresponding series of GSH analogs. ${ }^{30}$ As shown in Figure 6, a good linear correlation of the averaged amine $\mathrm{p} K_{\mathrm{a}}$ on $z_{\mathrm{C}}$ includes all disulfides studied, but secondary effects related to peptide sizes are also present. A correlation coefficient $R=-0.95(p=0.003, n=6)$ was found in the series of tripeptides. The slope of this correlation, $-0.16 \pm 0.03 \mathrm{pH}$ units per unit charge, is very similar to that observed in GSH analogs. The value of $R=-0.88$

(62) Gergely, A.; Nagypal, I. J. Chem. Soc., Dalton Trans. 1977, 11041108.

(63) Brunetti, A. P.; Lim, M. C.; Nancollas, G. H. J. Am. Chem. Soc. 1968, 90, 5120-5126.

(64) Bunting, J. W; Stefanidis, D. J. Am. Chem. Soc. 1990, 112, 779-786

(65) Kiss, T.; Sovago, I.; Gergely, A. Pure Appl. Chem. 1991, 63, 597-638.

(66) Ferretti, L.; Elviri, L.; Pellinghelli, M. A.; Predieri, G.; Tegoni, M. J. Inorg. Biochem. 2007, 101, 1442-1456.

(67) Corrie, A. M.; Williams, D. R. J. Chem. Soc., Dalton Trans. 1976, 1068-1072.

(68) Jelsch, C.; Didierjean, C. Acta Crystallogr., Sect. C 1999, 55, 15381540 .

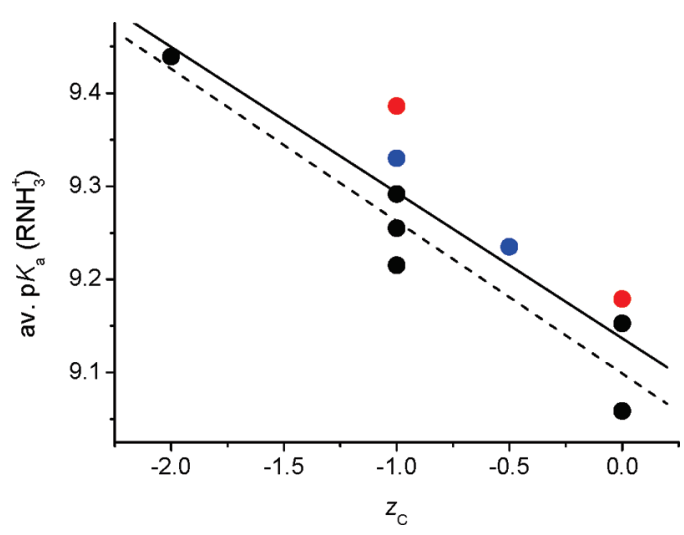

Figure 6. A linear correlation between the average value of the amine group dissociation constant $\left(\mathrm{av} . \mathrm{p} K_{\mathrm{a}}\left(\mathrm{RNH}_{3}{ }^{+}\right)\right)$and $z_{\mathrm{C}}$, the stoichiometric electronic charge on the $\mathrm{C}$-terminal residue in $\mathrm{H}_{2} \mathrm{~L}$ species for all ligands. Red, black, and blue circles represents di-, tri-, and mixed di-/tripeptide disulfides, respectively.

with the same slope was calculated for all peptides with an even higher significance ( $p=0.0008, n=10$; Figure 6). Notably, the difference of amine $\mathrm{p} K_{\mathrm{a}}$ values, $\mathrm{p} K_{1}-\mathrm{p} K_{2}$ did not correlate significantly with $z_{\mathrm{C}}(R=-0.55, p=$ $0.09, n=10)$.

The influence of $z_{\mathrm{C}}$ on amine $\mathrm{p} K_{\mathrm{a}}$ is particularly strong in the dipeptide disulfide $(\gamma \mathrm{EC})_{2}$. The presence of negatively charged $\mathrm{C}$-terminal carboxylates next to the glutamic acid residue results in the elevation of the average amine $\mathrm{p} K_{\mathrm{a}}$ by $0.09 \log$ units, compared to $(\gamma \mathrm{ECG})_{2}$, while the difference of these values between $(\gamma \mathrm{ECG}-\mathrm{OEt})_{2}$ and $(\gamma \mathrm{EC} \text {-OEt })_{2}$ is less than $0.02 \log$ units. The effect in the mixed disulfide $\gamma \mathrm{ECG}-\gamma \mathrm{EC}$ is intermediate, $0.04 \mathrm{log}$ units, vs $(\gamma \mathrm{ECG})_{2}$.

We interpret these results as evidence for a direct, throughspace electrostatic interaction between the protonated amine and the deprotonated $\mathrm{C}$-terminal carboxylate(s). The lack of effect on $\mathrm{p} K_{1}-\mathrm{p} K_{2}$ indicates that this interaction is confined to monomeric units of disulfides, behaving largely independently. The further confirmation of this effect is provided by the specific sensitivity of Gly, but not Cys protons, to the amine group deprotonation seen in NMR spectra (Figure 2, Supporting Information Table S3).

Larger differences of $\mathrm{p} K_{\mathrm{a}}$ values of the amine groups are observed for nondisulfide analogs with the modified thiol, S-methylglutathione, and glutathione sulfonic acid. This effect is consistent with our conformational model of GSH, which includes the $\mathrm{p} K_{\mathrm{a}}$ modifying effect, exerted on the amine by the deprotonated thiol group, or, in principle, any charged group in its vicinity. ${ }^{30}$

Thermodynamics of $\mathbf{Z n}$ (II) Complexes with GSSG. The $\mathrm{Zn}$ (II) complexation pattern in GSSG and its analogs includes two major complexes, $\mathrm{ZnL}^{2-}$ at neutral and weakly alkaline $\mathrm{pH}$ and $\mathrm{ZnH}_{-1} \mathrm{~L}^{3-}$ under more alkaline conditions, as well as two overlapping, minor species, $\mathrm{ZnHL}^{-}$and $\mathrm{Zn}_{2} \mathrm{~L}$ in weakly acidic solutions. The two previous potentiometric studies of $\mathrm{Zn}$ (II) coordination to GSSG were done under similar, although not identical, conditions $\left(T=25^{\circ} \mathrm{C}, I\right.$ of $0.15^{28}$ or $\left.0.20^{27}\right)$. The earlier of these studies proposed only the $\mathrm{ZnL}^{2-}$ complex. The model presented in the later one is similar to ours, except for its omission of the $\mathrm{ZnH}_{-1} \mathrm{~L}^{3-}$ species, and slightly lower formation constant values (ca. $0.4 \mathrm{log}$ units per $\mathrm{Zn}(\mathrm{II})$ ion). In contrast with the preceding studies, however, 
Scheme 2. Schematic Representation of Structures of Zn(II)-GSSG Complexes
A

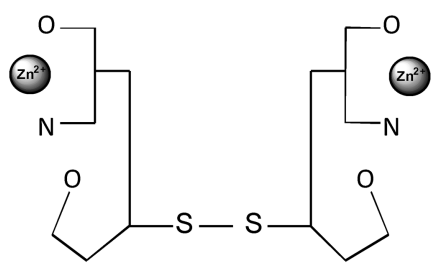

C

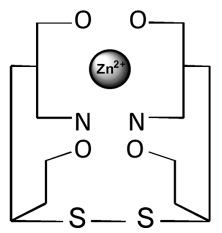

B

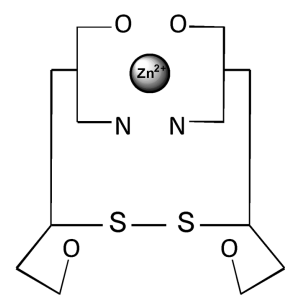

D

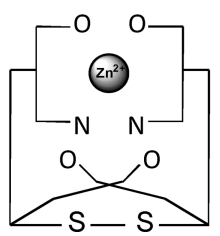

our potentiometric results were confirmed quantitatively by ${ }^{1} \mathrm{H}$ NMR spectroscopic titrations, as shown in Figure 4. These results, in particular the magnitudes of chemical shift effects, confirm the glutamic amines and carboxylates as $\mathrm{Zn}$ (II) binding sites in all complexes (Figures 3 and 4).

The stability constant of the $\mathrm{ZnHL}^{-}$complex, corrected for protonation of the uncomplexed amine $\left(\log K_{\mathrm{ZnHL}}=\right.$ $\left.\log \beta_{\mathrm{ZnHL}}-\log \beta_{\mathrm{HL}}\right)$ at $25^{\circ} \mathrm{C}$, equal to 4.50 , is quantitatively similar to $\log K_{\mathrm{ZnA}}$ values with $\mathrm{A}$ representing simple amino acids, ca. 4.2-4.7. ${ }^{69,70}$ However, as seen in Table 4, this value is a result of an unfavorable enthalpic effect, as opposed to low, but favorable $\Delta H$ effects for analogous amino acid complexes $\left(-5\right.$ to $\left.-15 \mathrm{~kJ} \mathrm{~mol}^{-1}\right)$, compensated by the entropic contribution, which is 2 to 3 times higher $\left(40-70 \mathrm{~J} \mathrm{~mol}^{-1} \mathrm{~K}^{-1}\right)$. These differences are consistent with the breaking of the electrostatic bridges between Glu moieties (enthalpic cost), compensated by an increased disorder (likely including the release of water molecules from the uncoordinated GSSG molecule). This complex may be "unfolded", with $\mathrm{Zn}$ (II) bonded solely to one glutamic unit, or "folded", with an additional coordination of the carboxylate from the second glutamic unit (see Scheme 2 for schematic structures of complexes discussed here and below). The comparison of $\log$ a $K_{\mathrm{ZnHL}}$ value of 4.50 with one of 4.17 , the analogous value determined for glutamine, the closest structural analog of the glutamic binding site in $\mathrm{GSSG}^{71}{ }^{71}$ is in favor of the folded structure, containing an additional, albeit weak $\mathrm{Zn}(\mathrm{II})$-ligand bond. This issue is explored in more detail in the next section.

The addition of the second $\mathrm{Zn}^{2+}$ ion to this complex to form $\mathrm{Zn}_{2} \mathrm{~L}, \mathrm{Zn}^{2+}+\mathrm{ZnHL}^{-} \leftrightarrows \mathrm{Zn}_{2} \mathrm{~L}+\mathrm{H}^{+}$, is entropydriven (Table 4). Two glutamic $\mathrm{Zn}$ (II) sites in $\mathrm{Zn}_{2} \mathrm{~L}$ carry positive charges, causing them to repulse each other. Hence, this complex cannot assume a folded structure. A high increase of entropy, accompanying its formation, provides further evidence for the folded conformation of $\mathrm{ZnHL}^{-}$.

(69) Arena, G.; Cali, R.; Cucinotta, V.; Musumeci, S.; Rizzarelli, E.; Sammartono, S. J. Chem. Soc., Dalton Trans. 1983, 1271-1278.

(70) Sovago, I.; Kiss, T.; Gergely, A. Pure Appl. Chem. 1993, 65, 10291080.

(71) Tewari, R. C.; Srivastava, M. N. J. Inorg. Nucl. Chem. 1973, 35, 2441-2446.
The high stability constant of the $\mathrm{ZnL}^{2-}$ species is due to a lowering of the amine $\mathrm{p} K_{\mathrm{a}}$ by $3.56 \log$ units, compared to uncomplexed GSSG. NMR titrations support the intuitive notion that this species contains both amine nitrogen residues coordinated to the $\mathrm{Zn}(\mathrm{II})$ ion. The formal process $\mathrm{Zn}^{2+}+\mathrm{L}^{4-} \leftrightarrows \mathrm{ZnL}^{2-}$ contains favorable enthalpic and entropic contributions, but interestingly the reaction $\mathrm{ZnHL}^{-} \leftrightarrows \mathrm{ZnL}^{2-}+\mathrm{H}^{+}$, which constitutes an important pathway for the formation of this complex (see Figure 4), is controlled purely by entropy (the enthalpic contribution amounts to less than $1 \mathrm{~kJ}$ per mole).

The formation of the $\mathrm{ZnH}_{-1} \mathrm{~L}^{3-}$ complex under alkaline conditions is confirmed by small, but evident changes of chemical shifts of $\alpha-\mathrm{Glu}, \beta$-Cys, and Gly protons, compared to those for the $\mathrm{ZnL}^{2-}$ complex (Figures 3 and 4). The $\mathrm{p} K_{\mathrm{a}}$ value for $\mathrm{ZnH}_{-1} \mathrm{~L}^{3-}$ formation obtained from glutamic and $\beta$-Cys protons was 9.37(3), only somewhat lower from the potentiometric value of 9.745(9). The low magnitudes of these NMR effects indicate that the binding mode of $\mathrm{ZnL}^{2-}$ is retained in this complex, thus excluding the possibility of an amide bond deprotonation. Therefore, the hydrogen ion must be released from a water molecule associated with the complex. The $\mathrm{p} K_{\mathrm{a}}$ value is rather low for a -2 charged complex (typical $\mathrm{p} K_{\mathrm{a}}$ values range between 8 and 10 positively charged complexes and are usually above 10 for neutral or -1 charged complexes). ${ }^{72-75}$

Correlations of Properties in GSSG Analogs. Similarly to the case of protonation equilibria, a deeper understanding of $\mathrm{Zn}(\mathrm{II})-\mathrm{GSSG}$ complexes can be gained from the analysis of tendencies in the series of $\mathrm{Zn}$ (II) complexes of disulfide analogs studied. As shown in Supporting Information Figure S2, the stabilities of individual complexes are very strongly dependent on basicities of amine groups. Correlation coefficients $R$ as high as -0.98 were found for $\mathrm{ZnHA}, \mathrm{Zn}_{2} \mathrm{~A}$, and $\mathrm{ZnA}$ complexes. Only the stabilities of $\mathrm{ZnH}_{-1} \mathrm{~A}$ complexes were a little less correlated, with $R=-0.91$. Inspired by the existence of the relationship between the amine basicities of disulfides and their C-terminal charges, discussed above, we performed analogous calculations, presented in Figure 7. Indeed, stabilities of all complexes exhibited strong correlations with $z_{\mathrm{C}}$. The qualities of these linear fits for $\mathrm{ZnHA}, \mathrm{Zn}_{2} \mathrm{~A}$, and $\mathrm{ZnA}$ complexes were somewhat lower than the previous ones, $R=-0.92,-0.87$, and -0.93 , respectively. Interestingly, the correlation with $z_{\mathrm{C}}$ was higher than that with $\mathrm{p} K_{1}+\mathrm{p} K_{2}$ for the $\mathrm{ZnH}_{-1}$ A complex, $R=-0.93$. Figure 7 demonstrates a very strict relationship between $\mathrm{Zn}$ (II) binding properties of $\mathrm{ZnHA}$ and $\mathrm{ZnA}$ complexes, with $R$ as high as 0.996 . These results allow one to conclude that the overall ability of GSSG analogs to bind $\mathrm{Zn}$ (II) is controlled directly by amine basicities, and indirectly by C-terminal charges. Nevertheless, significant secondary effects are present among the studied disulfides. The inspection of Supporting Information Figure S2 indicates that the impact of amine basicity on species stability

(72) Delgado, R.; Sun, Y.; Motekaitis, R. J.; Martell, A. E. Inorg. Chem. 1993, 32, 3320-3326.

(73) Gualtieri, R. J.; McBryde, W. A. E.; Powell, H. K. J. Can. J. Chem. 1979, 57, 113-118.

(74) Koike, T.; Takamura, M.; Kimura, E. J. Am. Chem. Soc. 1994, 116, 8443-8449.

(75) Menif, R.; Martell, A. E. Inorg. Chem. 1989, 28, 116-122. 

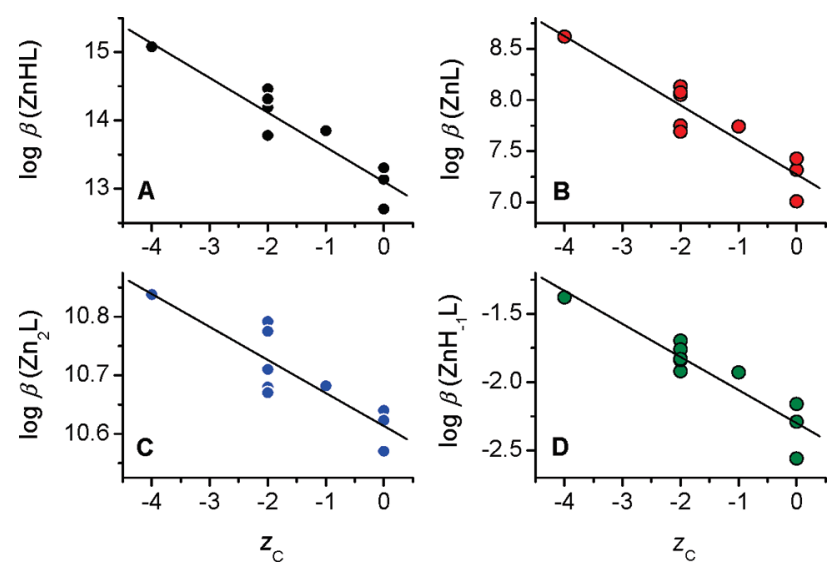

Figure 7. A linear correlation between $\log \beta$ values of $\mathrm{ZnHA}$ (A), $\mathrm{ZnA}$ (B), $\mathrm{Zn}_{2} \mathrm{~A}$ (C), and $\mathrm{ZnH}_{-1} \mathrm{~A}$ (D) complexes and $z_{\mathrm{C}}$, stoichiometric electronic charges of zinc-disulfide complexes.

is highest for $\mathrm{ZnHA}$ complexes, with a slope of the linear correlation of $3.0 \log \beta_{\text {ZnHA }}$ units per $1\left(\mathrm{p} K_{1}+\mathrm{p} K_{2}\right)$ unit, followed by $\mathrm{ZnA}$, a slope of $2.0 ; \mathrm{ZnH}_{-1} \mathrm{~A}$, a slope of 1.3 ; and $\mathrm{Zn}_{2} \mathrm{~A}$, as little as 0.36 units. These differences cannot be explained by a simple electrostatic mechanism, present in uncomplexed GSSG analogs, and require the presence of an additional bonding mechanism.

Figure 8 presents the relationship between equilibrium constants for reactions $\mathrm{Zn}^{2+}+\mathrm{H}_{2} \mathrm{~A} \leftrightarrows \mathrm{ZnHA}+\mathrm{H}^{+}$(top) and $\mathrm{Zn}^{2+}+\mathrm{H}_{2} \mathrm{~A} \leftrightarrows \mathrm{ZnA}+2 \mathrm{H}^{+}$(bottom) and amine basicities. These reactions provide actual processes of formation of these complexes, as $\mathrm{H}_{2} \mathrm{~A}$ is the predominant protonation form of disulfides in the $\mathrm{pH}$ range of formation of these complexes (cf. Figure 1 vs. Figure 4). They further demonstrate the presence of an additional factor, which increases the stability of complexes of tripeptides with unmodified C-terminal carboxylates. It accounts for ca. $0.3 \log$ units of the stability constant, corresponding to a $\Delta \Delta G$ of $1.6 \mathrm{~kJ} / \mathrm{mol}$ for both $\mathrm{ZnHA}$ and $\mathrm{ZnA}$ complexes. The mixed disulfides in which one unit belongs to the above family, and another is either shorter or modified, exhibit average stabilities, compared to parent symmetrical disulfides. Therefore, the mechanism in question is additive with respect to monomeric units of the disulfides.

The extremely tight correlation between $\mathrm{ZnHA}$ and $\mathrm{ZnA}$ stabilities and the conservation of the unblocked tripeptide effect further support the presence of similar conformations in these two species. The similarity of conformations between $\mathrm{ZnA}$ and $\mathrm{ZnH}_{-1} \mathrm{~A}$ complexes was discussed above for GSSG. Stabilities of these three species exhibited strong, albeit varied correlations on $\mathrm{p} K_{1}+\mathrm{p} K_{2}$, in contrast to that for $\mathrm{Zn}_{2} \mathrm{~A}$. The weak dependence on $\mathrm{p} K_{1}+\mathrm{p} K_{2}$ is therefore a consequence of the unfolded structures in the $\mathrm{Zn}_{2} \mathrm{~A}$ complexes, due to the electrostatic repulsion between +1 charged $\mathrm{Zn}$ (II) sites in them.

Notably, the highest relative abundance of $\mathrm{Zn}_{2} \mathrm{~A}$ complexes occurs for the weakest ligands, which do not carry negative charges on their C-termini, and is due to a relative weakness of $\mathrm{ZnHA}$ and $\mathrm{ZnA}$ complexes with these ligands.

Scheme 2 presents the possible modes of interaction in various complexes of GSSG and its analogs. The $\mathrm{Zn}_{2} \mathrm{~A}$ complexes are depicted in panel $\mathrm{A}$, with a possible weak interaction between $\mathrm{Zn}$ (II) binding sites and C-terminal

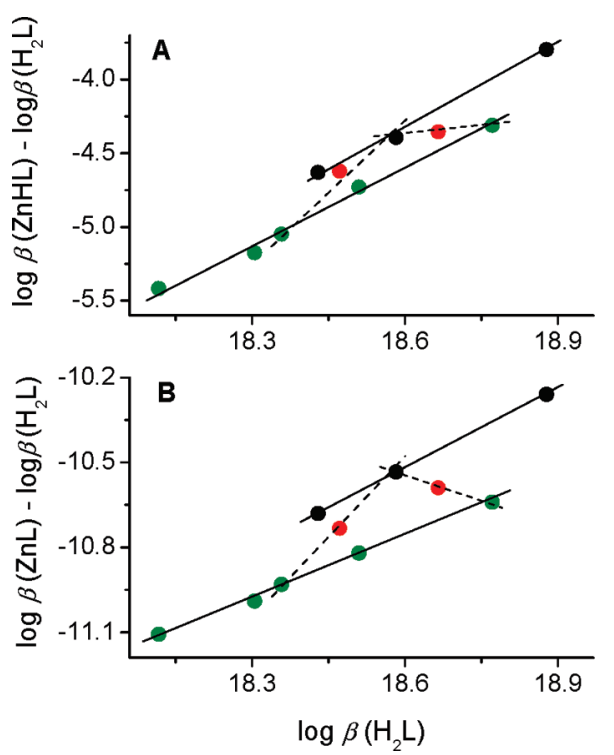

Figure 8. Correlations between stability constants of $\mathrm{ZnHA}$ and $\mathrm{ZnA}$ species defined by reactions $\mathrm{Zn}^{2+}+\mathrm{H}_{2} \mathrm{~L} \leftrightarrows \mathrm{ZnHL}(\mathrm{A})$ and $\mathrm{Zn}^{2+}+\mathrm{H}_{2} \mathrm{~L} \leftrightarrows$ $\mathrm{ZnL}$ (B). Compounds are color-coded as follows: disulfides of tripeptides with free $\mathrm{C}$-terminal function (olive); disulfides of di- and tripeptides with blocked C-terminal function, together with $\gamma \mathrm{EcG}$ (black); mixed disulfides (red).

carboxyl groups. Structure B depicts a hypothetical species with no C-terminal interaction. Such are clearly not dominant in complexes studied. Panel C presents a species with C-terminal groups interacting only within their monomeric units, while panel D presents a species with a "crossed" interaction, where each C-terminus may reach toward the other monomeric unit. The gain of $\mathrm{Zn}(\mathrm{II})$ binding stability of $1.5 \log$ unit per $1 \log$ unit of basicity of each amine (slope of 3 vs $\mathrm{p} K_{1}+\mathrm{p} K_{2}$ ) clearly indicates the participation of structure D in ZnHA complexes, with C-terminal groups providing multiple interactions with the first coordination sphere around the $\mathrm{Zn}$ (II) ion. Structure $\mathrm{C}$ might be assumed to correspond to $\mathrm{ZnA}$ complexes, with a stability gain directly corresponding to amine basicity. However, such a 1:1 relation would require a phenomenally rigid species, incompatible with the noncovalent character of C-terminal interactions. Therefore, the reality of closed complexes is best depicted by mixtures of structures $\mathrm{C}$ and $\mathrm{D}$, with a higher proportion of structure $\mathrm{C}$ in $\mathrm{ZnHL}$ complexes.

A weak negative correlation was found between the stability of $\mathrm{ZnHA}$ complexes and the stepwise constant of formation of $\mathrm{ZnA}$ complexes, slope $=-0.18 \mathrm{log}$ units. This effect is most likely due to a slight shortening of $\mathrm{Zn}-\mathrm{N}$ bonds, expected in stronger complexes, which has to be compensated conformationally and induces a slight strain in $\mathrm{ZnA}$ species.

The stronger dependence of the stability of $\mathrm{ZnH}_{-1} \mathrm{~A}$ complexes on $z_{\mathrm{C}}$ provides a further proof for the location of C-terminal groups in the vicinity of the $\mathrm{Zn}$ (II) binding site. The correlations between the water $\mathrm{p} K_{\mathrm{a}}$ and amine basicity or ZnA stability are weaker, with an $R$ of 0.86 (Supporting Information Figure S3), but the deviation from linearity is mostly due to the anomalous behavior of the D-Cys analog, where the $\mathrm{Zn}(\mathrm{II})$-bonded water molecule is much more acidic. In general, the value of the water $\mathrm{p} K_{\mathrm{a}}$ is influenced by overall electrostatics, as well as 
specific effects of the $\mathrm{C}$-terminal carboxylates. The average water $\mathrm{p} K_{\mathrm{a}}$ value for the group of derivatives containing at least one tripeptide carboxylate unit (three unblocked tripeptides and two mixed disulfides) is 9.80 , vs. 9.64 in the remaining five analogues. This difference is statistically significant only at a 0.19 level but becomes significant at a 0.03 level upon removal of those compounds with the strongest electrostatic effects $(\mathrm{Zn}(\mathrm{II})-\mathrm{GSSG}$ from the first group and $\mathrm{Zn}(\mathrm{II})-(\gamma \mathrm{EC})_{2}$ from the second group (the average water $\mathrm{p} K_{\mathrm{a}}$ values become then 9.75 vs 9.55)).

Table 5 presents also the competitivity index (CI) values, calculated for $10 \mathrm{mM} \mathrm{Zn}$ (II) and disulfide ligands at $\mathrm{pH} 7.4\left(\mathrm{CI}_{0.01 / 7.4}\right)$. CI was developed by us to aid comparisons of metal binding abilities of ligands and sets of ligands possessing various stoichiometries. ${ }^{60} \mathrm{It}$ is defined as the logarithm of the conditional stability constant of MZ, the binary metal complex of a hypothetical molecule $\mathrm{Z}$ which takes up the same proportion of the metal ion $\mathrm{M}$, as all actual complexes under consideration. For sufficiently strongly binding systems, where the amount of uncomplexed $\mathrm{M}$ is insignificant, this proportion is $50 \%$. The appropriate formula is provided in the footnote to Table 5.

Defined in this way, $\mathrm{CI}_{0.01 / 7.4}$ essentially combines binding abilities of $\mathrm{ZnHA}$ and $\mathrm{ZnA}$ complexes. The span of $\mathrm{CI}_{0.01 / 7.4}$ values is only $0.7 \mathrm{log}$ units for all compounds presented in Table 5, and most of them are confined within $0.2 \log$ units, confirming that $\mathrm{Zn}$ (II) binding is mostly due to the pair of N-terminal chelates common to all disulfides studied. The bonding in GSSG is particularly effective, second only to that of the Glu analog, and equal, within the experimental error, to that of dipeptide carboxylates, indicating that specific interactions of Gly in GSSG fully compensate the stronger electrostatics of dipeptides.

Structures of $\mathrm{Zn}(\mathrm{II})$ Complexes of GSSG and Its Glycine Ester. A heavy overlap between the $\mathrm{pH}$ profiles of formation of minor $\mathrm{ZnHL}^{-}$and $\mathrm{Zn}_{2} \mathrm{~L}$ species and that of the major $\mathrm{ZnL}^{2-}$ precluded NMR-based characterization of their structures. However, the above discussion proved that $\mathrm{Zn}_{2} \mathrm{~L}$ has an unfolded structure, in which two $\mathrm{Zn}$ (II) sites do not interact with each other, while $\mathrm{ZnHL}^{-}$shares the folded, coiled structure with $\mathrm{ZnL}^{2-}$ and $\mathrm{ZnH}_{-1} \mathrm{~L}^{3-}$.

The structure of the $\mathrm{ZnL}^{2-}$ complex is fairly rigid, as indicated by such NMR spectral features as differentiation of Glu- $\beta$ protons and a selective change of chemical shift of one of the Gly protons, correlated with the formation of the $\mathrm{ZnL}^{2-}$ complex (Figure 3). Both of these features result from the spatial fixing of these geminal protons in nonequivalent distances relative to their adjacent carboxylate oxygens. The mechanism of this fixing is provided by the structure presented in Figure 5, where $\mathrm{Zn}(\mathrm{II})$ is coordinated directly by Glu carboxylates and indirectly by Gly carboxylates, through hydrogen bonds between their oxygen atoms and $\mathrm{Zn}(\mathrm{II})$-bonded water molecules. The latter interaction adds the stability of $\mathrm{Zn}$ (II) binding specifically in those tripeptide disulfides which contain unblocked C-terminal carboxylates, in contrast with weaker $\mathrm{H}$-bonding available in those disulfides which have carboxyl functions modified by esterification or amidation. Hydrogen bonding of $\mathrm{Zn}$ (II)-coordinated water molecules to noncoordinating carboxylates is common

(76) Hambley, T. W.; Christopherson, R. I.; Zvargulis, E. S. Inorg. Chem. $1995,34,6550-6552$. in the solid state. ${ }^{76,77}$ Such structures were also proposed in several cases of small complexes in solution, based on indirect arguments. ${ }^{78-80}$ The overall gain of $\mathrm{Zn}$ (II) binding stability between the series with strong H-bonding to the carboxylate and the series with weaker $\mathrm{H}$-bonding to carbonyl oxygens is low, $1.6 \mathrm{~kJ} / \mathrm{mol}$. As discussed extensively above, the nondirectional electrostatic interaction provides a major part of $\mathrm{Zn}$ (II) stabilization. Therefore, an equilibrium between the $\mathrm{H}$-bonded and non-H-bonded species should be present in all complexes studied. Our data do not allow for estimation of the corresponding equilibrium constants. Neither experimental nor theoretical data on energetics of hydrogen bonds of $\mathrm{Zn}$ (II)bonded water molecules to noncoordinated carboxylates are available. However, the above discussion of strong correlations of charges, basicities, and complex stabilities suggests a high proportion of structures C and D of Scheme 2 vs structure B, especially in the complexes of unblocked tripeptide disulfides.

The structure presented in Figure 5 also explains the rigidity of the disulfide bridge region, which manifested itself in the extreme value of the ${ }^{3} J_{\mathrm{H \alpha H} \beta}$ coupling constant. The conformation with $\chi_{1}=-60^{\circ}$ is strongly stabilized sterically. The changes of these angles are prevented on one side by a hindrance between $\beta$ protons of opposite Cys residues and on the other side by a hindrance between $\beta$-Cys protons and peptide oxygens of opposite Cys residues.

Biological Relevance of $\mathrm{Zn}(\mathrm{II})$-GSSG Complexes. Two factors should be taken into account when analyzing the possible relevance of the $\mathrm{Zn}(\mathrm{II})-\mathrm{GSSG}$ system in a biological environment: one is its relative stability, which governs the possibility of complex formation in vivo, and another is the presence of special features, which might make them important even at a low abundance. The first issue can be approached with the use of the competivity index $(\mathrm{CI})$, because it provides a method of estimating the relevance of particular complexes in a partially characterized equilibrium. ${ }^{60}$ As mentioned above, the CI values are concentration-dependent and therefore allow inclusion of the effects of absolute and relative abundances of individual competitors. The $\mathrm{CI}_{0.01 / 7.4}$ value calculated for GSSG, 4.22 (Table 5), is lower than those calculated for likely biological low molecular weight $\mathrm{Zn}$ (II) ligands, ${ }^{67,70}$ ATP (5.05), GSH (4.73), and His (4.83), but the difference is not overwhelming. A direct calculation involving all four ligands in an equimolar mixture indicates the following distribution of $\mathrm{Zn}(\mathrm{II})$ : GSSG, 3.7\%; ATP, 22.4\%; GSH, $33.9 \%$; His, $40.0 \%$. Furthermore, taking into account that all three ligands exist intracellularly at concentrations much higher than GSSG and available $\mathrm{Zn}$ (II) levels are in the nano- to picomolar range, ${ }^{9,14-17,19,44,45}$ these calculations indicate that the formation of $\mathrm{Zn}(\mathrm{II})-\mathrm{GSSG}$ complexes intracellularly is unlikely.

(77) Fu, X. C.; Li, M. T.; Wang, C. G.; Wang, X. Y. Acta Crystallogr. Sect. C 2006, 62, m13-m15.

(78) Nagypal, I.; Farkas, E.; Gergely, A. J. Inorg. Nucl. Chem. 1974, 37, 2145-2149.

(79) Pettit, L. D.; Swash, J. L. M. J. Chem. Soc., Dalton Trans. 1976, 2416-2419.

(80) Kiss, T. In Biocoordination Chemistry, coordination equilibria in biologically active systems; Burger, K., Ed.; Ellis Horwood: Chichester, U. K., 1990; pp 56-134. 
To further test whether or not GSSG can compete with zinc components of biological fluids, we applied FluoZin-3, a fluorescent chelating sensor commonly used in in vivo and in vitro studies of $\mathrm{Zn}$ (II) distribution, as a thermodynamic model of a zinc pool. $9,19,44,45$ The sensor becomes highly fluorescent upon $\mathrm{Zn}$ (II) binding and has moderateto-high affinity for $\mathrm{Zn}(\mathrm{II})\left(K_{\mathrm{d}}=8.9 \mathrm{nM}\right)$. Figure 9 presents the fluorescence decrease of partially saturated FluoZin-3 with Zn(II) $(0.1 \mu \mathrm{M}$ FluoZin-3 and $0.05 \mu \mathrm{M}$ $\mathrm{Zn}(\mathrm{II}))$ in the presence of a wide range of GSSG concentrations. Initial strong emission became significantly quenched $(33 \%)$ after the addition of $1 \mathrm{mM}$ of GSSG, while $\mathrm{pZn}\left(-\log \left[\mathrm{Zn}^{2+}\right]\right)$ increased from 8.29 to 8.46 . The addition of GSSG in the range of its intracellular concentration hardly affected the FluoZin-3 fluorescence. FluoZin-3 was demonstrated to interfere with the intracellular zinc pool, and therefore such a competition experiment may be considered as a benchmark for significant participation of a competing ligand in $\mathrm{Zn}$ (II) distribution. $9,19,44,45$ The absence of such an effect clearly confirms that GSSG cannot be a significant $\mathrm{Zn}$ (II) chelator in intracellular fluids. However, the situation may be quite different in the extracellular space, where available $\mathrm{Zn}(\mathrm{II})$ pools may exceed micromolar levels, ${ }^{81-83}$ and there are much fewer competing ligands (e.g., ATP and GSH are absent). The lack of quantitative data in this respect for this quickly changing and highly variable milieu prevented us from performing appropriate calculations, but the potential presence of $\mathrm{GSSG}-\mathrm{Zn}$ (II) complexes will be possible to test in cell culture studies.

The above results allowed us to limit the discussion of special features of $\mathrm{Zn}(\mathrm{II})-\mathrm{GSSG}$ complexes to the $\mathrm{ZnL}^{2-}$ complex. Two features of this complex appear to be important and may be functionally related to each other. One is the presence of $\mathrm{Zn}(\mathrm{II})$-bound water molecules susceptible to deprotonation, and another is the folding of Gly residues back on them. Such water molecules, readily convertible into hydroxyl ions, are crucial for the action of a great number of $\mathrm{Zn}(\mathrm{II})$ enzymes, such as peptidases, esterases, phosphatases, etc., as well as their synthetic models. ${ }^{84}$ We tested whether the $\mathrm{Zn}(\mathrm{II})-\mathrm{GSSG}$ complex might act as an esterase or phosphatase at $\mathrm{pH}$ 7.4, on commonly used substrates 4-nitrophenyl acetate and tris(4-nitrophenyl) phosphate, respectively, according to standard procedures and conditions. ${ }^{85,86}$ The gain in hydrolysis rate was within the experimental error in each case (data not shown), most likely due to a very low abundance of the $\mathrm{ZnH}_{-1} \mathrm{~L}^{3-}$ complex, which possesses the catalytic hydroxyl ion at this $\mathrm{pH}$ (ca. $0.4 \%$ of total zinc).

(81) Frederickson, C. J.; Giblin, L. J.; Balaji, R. V.; Masalha, R.; Frederickson, C. J.; Zeng, Y.; Lopez, E. V.; Koh, J. Y.; Chorin, U.; Besser, L.; Hershfinkel, M.; Li, Y.; Thompson, R. B.; Krężel, A. J. Neurosci. Methods 2006, 154, 19-29.

(82) Frederickson, C. J.; Giblin, L. J.; Krężel, A.; McAdoo, D. J.; Mueller, R. N.; Zeng, Y.; Balaji, R. V.; Masalha, R.; Thompson, R. B.; Fierke, C. A.; Sarvey, J. M.; de Valdenebro, M.; Prough, D. S.; Zornow, M. H. Exp. Neurol. 2006, 198, 285-293.

(83) Opoka, W.; Sowa-Kućma, M.; Kowalska, M.; Baś, B.; Gołembiowska, K.; Nowak, G. J. Physiol. Pharmacol. 2008, 59, 477-487.

(84) Parkin, G. Chem. Rev. 2004, 104, 699-768.

(85) Verpoorte, J. A.; Mehta, S.; Edsall, J. T. J. Biol. Chem. 1967, 242, $4221-4229$.

(86) Goldberg, D. P.; diTargiani, R. C.; Namuswe, F.; Minnihan, E. C.; Chang, S.; Zakharov, L. N.; Rheingold, A. L. Inorg. Chem. 2005, 44, 75597569 .
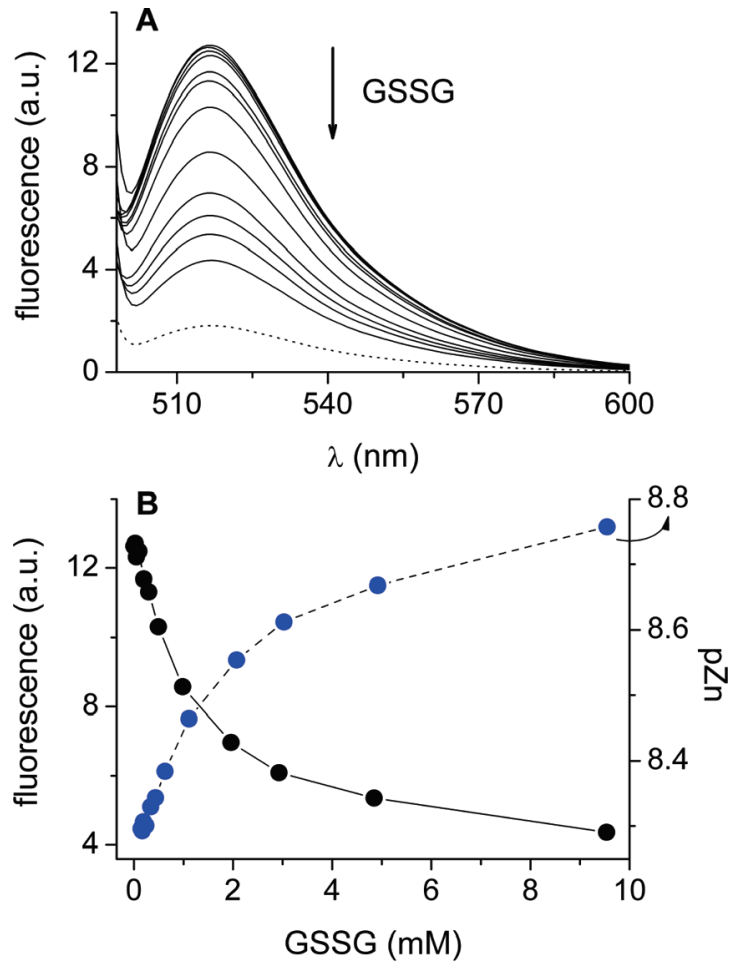

Figure 9. The competition for $\mathrm{Zn}(\mathrm{II})$ between FluoZin-3 and GSSG. Initial concentrations of FluoZin-3 and $\mathrm{Zn}$ (II) were 0.1 and $0.05 \mu \mathrm{M}$, respectively. Fluorescence spectra were recorded at $25{ }^{\circ} \mathrm{C}$ after the addition and equilibration of $0-9.6 \mathrm{mM}$ GSSG (A). pZn values at each particular step were calculated according to the following equation: $\mathrm{pZn}$ $=-\log \left(K_{\mathrm{d}} \times\left(F-F_{\min }\right) /\left(F_{\max }-F_{\min }\right)\right)$, where $F_{\max }$ and $F_{\min }$ were measured after the addition of $100 \mu \mathrm{M} \mathrm{ZnSO}_{4}$ and $100 \mu \mathrm{M}$ EDTA (dotted line), to the initial sample (B).

Therefore, the presence of interactions between zincbound water molecules and Gly carboxylates in GSSG may be treated as a measure to quench the catalytic activity of $\mathrm{Zn}(\mathrm{II})$. The blocking of this interaction lowered the $\mathrm{p} K_{\mathrm{a}}$ of water by ca. $0.2 \log$ units, increasing the abundance of the potential catalyst by $60 \%$. On the other hand, one may conceive of the existence of specific targets for $\mathrm{Zn}(\mathrm{II})-\mathrm{GSSG}$, complexes, e.g., specific hydrolysis substrates which may activate $\mathrm{Zn}$ (II)-bound water by pulling the carboxylates away. The very specific structures of $\mathrm{Zn}(\mathrm{II})$ complexes of GSSG certainly warrant further studies of these issues.

\section{Conclusions}

The correlated thermodynamic and NMR structural description of protonation equilibria and complex formation between $\mathrm{Zn}$ (II) ions and GSSG and its analogs revealed the role of the Gly residue in complex stabilization and structuring. The specific, coiled structures of major GSSG complexes, including specifically bound water molecules, result from the concerted action of electrostatic interactions and hydrogen bonding. A similarly intricate network of interactions is present in the structure of the ternary $\mathrm{Zn}$ (II) complex with GSH and L-histidine presented by us previously. ${ }^{56}$ Such an interplay of individually weak interactions is more and more frequently found to govern strong thermodynamic effects. ${ }^{87}$ The $\mathrm{Zn}(\mathrm{II})-\mathrm{GSSG}$ complexes were not found to be active as

(87) Schlund, S.; Schmuck, C.; Engels, B. J. Am. Chem. Soc. 2005, 127, $11115-11124$. 
hydrolases against nitrophenyl ester and phosphate substrates, but as argued above, studies into their potential biological functions and reactivities should be continued.

Acknowledgment. This work was sponsored in part by the Polish Ministry of Science and Higher Education, Grant No. N N302 137735, and The Foundation for Polish Science, Grant No. HOM/2008/8B. The authors thank Ms. Katarzyna Piątek, Dr. Edyta Kopera, and Mr. Adam Pomorski for their assistance in experiments.
Supporting Information Available: The $\mathrm{p} K$ values of chemical shifts of nonexchangeable protons of GSSG; ${ }^{1} \mathrm{H}$ chemical shift of $\mathrm{Zn}(\mathrm{II})-\mathrm{GSSG}$ and $\mathrm{Zn}(\mathrm{II})-(\gamma \mathrm{ECG}-\mathrm{OEt})_{2}$ complexes; integrals of nondiagonal crosspeaks in ROESY NMR spectra; families of lowest energy conformers of $\mathrm{Zn}(\mathrm{II})-\mathrm{GSSG}$ and $\mathrm{Zn}(\mathrm{II})-(\gamma \mathrm{ECG}-\mathrm{OEt})_{2}$; the lowest energy conformers of the $\mathrm{Zn}(\mathrm{II})-(\gamma \mathrm{ECG}-\mathrm{OEt})_{2}$ complex; correlations between $\log \beta$ values of $\mathrm{ZnHL}, \mathrm{ZnA}, \mathrm{Zn}_{2} \mathrm{~A}$, and $\mathrm{ZnH}_{-1} \mathrm{~L}$ complexes and $\log \beta$ values of $\mathrm{H}_{2} \mathrm{~L}$ species; correlation between $\log \beta$ values of the $\mathrm{ZnL}$ complex and the $\mathrm{p} K_{\mathrm{OH}}$ values. This material is available free of charge via the Internet at http://pubs.acs.org. 